NBER WORKING PAPER SERIES

\title{
AMERICANS' DEPENDENCY ON SOCIAL SECURITY
}

\author{
Laurence J. Kotlikoff \\ Ben Marx \\ Pietro Rizza \\ Working Paper 12696 \\ http://www.nber.org/papers/w12696
NATIONAL BUREAU OF ECONOMIC RESEARCH
1050 Massachusetts Avenue
Cambridge, MA 02138 \\ November 2006
}

We thank the Social Security Administration and the Michigan Retirement Research Center for research support. The views expressed herein are those of the author(s) and do not necessarily reflect the views of the National Bureau of Economic Research.

(C) 2006 by Laurence J. Kotlikoff, Ben Marx, and Pietro Rizza. All rights reserved. Short sections of text, not to exceed two paragraphs, may be quoted without explicit permission provided that full credit, including (C) notice, is given to the source. 
Americans' Dependency on Social Security

Laurence J. Kotlikoff, Ben Marx, and Pietro Rizza

NBER Working Paper No. 12696

November 2006

JEL No. H22,H55

\begin{abstract}
$\underline{\text { ABSTRACT }}$
This paper determines the standard of living reductions that young, middle aged, and older households would experience were the U.S. government to cut Social Security benefits (but not taxes) to deal with its well documented (see Gokhale and Smetters, 2005) long-term fiscal crisis. To determine preand post-retirement living standards in the absence and presence of Social Security benefit cuts the paper relies on ESPlanner, a financial planning software program. ESPlanner calculates a household's highest sustainable living standard taking into account the household's economic resources including its claims to future Social Security benefits. The program also incorporates borrowing/liquidity constraints that limit households' abilities to smooth their living standards over their life cycles. The analysis considers both stylized single and married households of different ages and resource levels as well as actual households sampled from the 2004 Federal Reserve Survey of Consumer Finances (SCF). The extent of current and future living standard reductions in response to announcements of future Social Security benefit cuts depends critically on the age of the household, when the cuts are announced, the size of the cuts, the income of the household, and the degree to which the household is liquidity constrained. For our stylized households on the brink of retirement the complete elimination of Social Security benefits would entail retirement living standards reductions ranging from roughly one third to one hundred percent depending on the household's income. Our SCF findings also point to a strong dependency on Social Security. Indeed, 41 percent of older SCF couples and 33 percent of SCF singles would experience a living standard reduction of 90 percent or more were Social Security benefits eliminated. A surprising finding is the major dependency of very high-income households on Social Security. Take the highest earning couple in our stylized sample. This couple earns $\$ 500,000$ per year from age 30 through age 64 when it retires. It enters retirement with over $\$ 2.3$ million in assets. But given the length of its potential retirement, the modest real return it can safely earn on its assets, its off-the-top housing expenses, and its tax payments, this household is highly dependent on Social Security benefits, notwithstanding their taxable status. Indeed, were this household denied all its Social Security benefits on the eve of its retirement, it would suffer a 35.6 percent reduction in its living standard throughout retirement.
\end{abstract}

Laurence J. Kotlikoff

Department of Economics

Boston University

270 Bay State Road

Boston, MA 02215

and NBER

kotlikoff@bu.edu

Ben Marx

Department of Economics

270 Bay State Road

Boston, MA 02215

benmarx@bu.edu
Pietro Rizza

Department of Economics

270 Bay State Road

Boston, MA 02215

prizza@bu.edu 


\section{Introduction}

According to a recent, highly detailed, and conservative estimate by Gokhale and Smetters (2005), the present value difference between the U.S. government's projected future expenditures and its projected future tax receipts exceeds $\$ 60$ trillion! Closing this enormous fiscal gap requires massive and extremely painful expenditure cuts, tax hikes, or both. Delaying such adjustments exacerbates the fiscal crisis and raises the prospect of a major financial/economic meltdown, including high and growing rates of inflation if the government uses the printing press to "pay" its bills.

The inevitable adjustment to a sustainable fiscal policy will, no doubt, involve a variety of different tax increases and expenditure reductions. But these tax hikes and spending cuts need not be explicit. Instead, they may arise by allowing price hikes to outpace the indexation of tax and expenditure provisions.

Will Social Security benefits come under the chopping block? Especially the Social Security benefits of the rich? No one can say for sure. But what we can say and do study in this paper is how potential Social Security benefit cuts would impact the wellbeing of different American households.

Specifically, we examine the living standard impacts of immediate and permanent 30 percent and 100 percent cuts in Social Security benefits. In so doing, we don't claim that cuts of either of these magnitudes will necessarily arise or that any Social Security benefit cuts will be announced any time soon. Instead, we examine cuts of these magnitudes to illustrate the dependency of the population on Social Security and to help policymakers calibrate the cost to Americans of this form of policy adjustment.

One may object to our exclusive focus on Social Security benefits in discussing Americans' dependency on the system. Were Social Security tax cuts coupled with Social Security benefit cuts, working Americans would be able to use their tax savings to limit the decline in their current and future living standards. But given Social Security's fiscal condition, the prospect for reductions in taxes earmarked to finance Social Security benefits seems remote.

In determining pre- and post-retirement living standards in the absence and presence of Social Security benefit cuts we rely on ESPlanner, a financial planning software program. ESPlanner calculates a household's highest sustainable living standard taking into account the household's economic resources including its claims to future Social Security benefits. The program also incorporates borrowing/liquidity constraints that limit households' abilities to smooth their living standards over their life cycles.

Our analysis considers both stylized single and married households of different ages and resource levels as well as actual households sampled from the 2004 Federal Reserve Survey of Consumer Finances. Given the progressive nature of the Social Security benefit formula, one would expect across-the-board benefit cuts to impact low-income households disproportionately relative to high income households. And given that a) benefit cuts have a larger present value impact on resources the closer they are to being received and b) younger households have more 
time to adjust their saving behavior to prospective benefit cuts, one would expect older households to experience disproportionately larger living standard reductions than younger ones.

These expectations must, however, be modified if some households are borrowing/liquidity constrained. Compare, for example, two young households that are identical except that one is liquidity constrained, while the other can borrow to smooth its living standard. The liquidityconstrained household will experience no change in its current living standard from future Social Security benefit cuts because it's not financing current consumption out of those future benefits. In contrast, the unconstrained young household will experience an immediate reduction in its living standard because it is financing its current spending in part from its future Social Security income. The flip side of this coin is that the liquidity constrained household will experience a larger percentage decline in living standard at retirement than will the non-liquidity constrained household.

This assumes that the liquidity constraints are, themselves, unaffected by cuts in Social Security benefits. But, as shown here, large enough benefit cuts, by reducing or eliminating the future income against which households wish to borrow, transforms borrowing-constrained households into non-borrowing-constrained households. At that point, these households can no longer rely on Social Security to finance their retirements and must save on their own. Doing so entails a drop in their current consumption spending and, thus, current living standard.

Given the importance of liquidity constraints for the timing of consumption adjustments in response to Social Security benefit cuts, it's important to show households' living standard adjustments at different stages of their life cycles. This, indeed, is what we do.

Our findings for the stylized households may be summarized as follows. The extent of current and future living standard reductions in response to announcements of future Social Security benefit cuts depends critically on the age of the household, when the cuts are announced, the size of the cuts, and the income of the household. Social Security benefit cuts of 30 percent, if announced when a household is about to retire, can lead to retirement living standard reductions ranging from roughly one third to one tenth depending on the household's income. These reductions in living standard are substantially reduced if the household learns at younger ages about the benefit cuts and, consequently, has a longer time period over which to adjust.

For our stylized households on the brink of retirement the complete elimination of Social Security benefits would entail retirement living standards reductions ranging from roughly one third to one hundred percent depending on the household's income. This presumes that the announcement is made when the household hits age 65. If the announcement were made when the household was age 35, the retirement living standard reduction would range from roughly 20 to 50 percent.

The most surprising finding in our analysis of stylized households is the major dependence of very high-income households on Social Security. Take the highest earning couple in our stylized sample. This couple earns $\$ 500,000$ per year from age 30 through age 64 when it retires. It enters retirement with over $\$ 2.3$ million in assets. But given the length of its potential retirement, the modest real return we assume it can safely earn on its assets, its off-the-top 
housing expenses, and its tax payments, this household is highly dependent on Social Security benefits, notwithstanding their taxable status. Indeed, were this household denied all its Social Security benefits on the eve of its retirement, it would suffer a 35.6 percent reduction in its living standard throughout retirement.

Our findings based on the SCF are quite similar to those based on the stylized households. Almost two-thirds of young SCF households and over a quarter of middle aged SCF households are borrowing constrained. Consequently, their immediate living standard falls relatively little in response to a 30 percent benefit cut, but much more substantially in the case of a 100 percent benefit cut. In the case of elderly SCF respondents their immediate living standards are highly dependent on Social Security. Indeed, 41 percent of older couples and 33 percent of singles would experience a living standard reduction of 90 percent or more were Social Security benefits eliminated.

We proceed in section 2 with a description of ESPlanner. Section 3 describes our stylized households and reports the living standard effects of the two alternative benefit cuts. Second 4 does the same for our Federal Reserve's 2004 Survey of Consumer Finances data. Section 5 concludes.

\section{ESPlanner}

ESPlanner determines a households highest sustainable living standard within each non-liquidity constrained interval of its life and the consumption, saving, and term life insurance holdings needed to smooth the household's living standard within each non-constrained interval. The program uses dynamic programming in forming its recommendations. Dynamic programming is needed to deal both with potential borrowing constraints and with non-negativity constraints on life insurance holdings.

The program takes into account the following user-specified inputs: the household's state of residence, current and future planned children and their years of birth, current and future regular and self-employment earnings, current and future special expenditures and receipts (as well as their tax status), current and future levels of a reserve fund, current regular and retirement account balances, current and future own and employer contributions to retirement accounts (with Roth IRAs treated separately), current and future primary and vacation home values, mortgages, rental expenses, and other housing expenditures, current and future states of residence, ages of retirement account withdrawals, ages of initial Social Security benefit receipt, past and future covered Social Security earnings, desired funeral expenses and bequests, current regular saving and life insurance holdings, the economies of shared living, the relative cost of children, the extent of future changes in Social Security benefits, the extent of future changes in federal income taxes, FICA taxes, and state income taxes, current and future pension and annuities (including lump sum and survivor benefits), the degree to which the household will annuitize its retirement account assets, and values of future earnings, special expenditures, receipts, and other variables in survivor states in which either the head or her spouse/partner is deceased. 
The living standard of members of a household is defined by ESPlanner as the amount of consumption expenditure an adult would need make to enjoy as a single person with no children the same living standard she enjoys in the household. The equation relating a household's living standard per member to its total consumption expenditure takes into account economies in shared living and the relative cost of children. ${ }^{1}$ Consumption expenditure is defined by ESPlanner as all expenditures apart from special expenditures, such as college tuition for children, housing expenditures, taxes, life insurance premiums, regular saving, and contributions to retirement accounts.

\section{ESPlanner's Tax Calculations}

ESPlanner makes highly detailed federal income, FICA, and state-specific income tax as well as Social Security benefit calculations. These tax and benefit levels are the only non-user specified variables influencing the program's consumption smoothing calculations.

The program's federal and state income-tax calculators determine whether the household should itemize its deductions, compute deductions and exemptions, deduct from taxable income contributions to tax-deferred retirement accounts, include in taxable income withdrawals from such accounts as well as the taxable component of Social Security benefits, check, in the case of federal income taxes, for Alternative Minimum Tax liability, and calculate total tax liabilities after all applicable refundable and non-refundable tax credits including the Earned Income Tax Credit and the Child Credit. These federal and state tax calculations are made separately for each year that the couple is alive as well as for each year a survivor may be alive.

Given the non-linearity of tax functions, one can't determine a household's tax rates in future years without knowing its regular asset and other taxable income in those years. But one can't determine how much a household will consume and save and thus have in asset income in future years without knowing the household's future taxes. Hence, we have a chicken and egg, i.e., a simultaneity problem that needs to be resolved to make sure that consumption and saving decisions are consistent with the future tax payments they help engender.

\section{ESPlanner's Social Security Benefit Calculations}

In determining Social Security benefits the program takes full account of the earnings test, early retirement reduction factors, the delayed retirement credit, the re-computation of benefits, the family benefit maximum, the phase-in to the system's ultimate age-67 normal retirement age, as well as offset and windfall elimination provisions.

ESPlanner's survivor tax and benefit calculations for surviving wives (husbands) are made separately for each possible date of death of the husband (wife). I.e., ESPlanner considers separately each date the husband (wife) might die and calculates the taxes and benefits a surviving wife (husband) and her (his) children would receive each year thereafter. Moreover, in

\footnotetext{
${ }^{1}$ Let $C$ stand for a household's total consumption expenditure, $s$ for its living standard per equivalent adult, $k_{i}$ for the number of children age $i, \theta_{i}$ for relative cost of a child age $i, N$ for the number of adults, and $v$ for the degree of economies of shared living. The relationship between $C$ and $s$ in a given year is $C=s\left(N+\Sigma \theta_{i} k_{i}\right)^{v}$.
} 
calculating survivor-state specific retirement, survivor, mother, father, and child dependent and survivor Social Security benefits, ESPlanner takes account of all the just-mentioned benefit adjustment factors.

\section{ESPlanner's Algorithm}

ESPlanner's calculates time-paths of consumption expenditure, taxable saving, and term life insurance holdings in constant (2001) dollars. Consumption in this context is everything the household gets to spend after paying for its "off-the-top" expenditures - its housing expenses, special expenditures, life insurance premiums, special bequests, taxes, and net contributions to tax-favored accounts. Given the household's demographic information, preferences, borrowing constraints, and non-negativity constraints on life insurance, ESPlanner calculates the highest sustainable and smoothest possible living standard over time, leaving the household with zero terminal assets (apart from the equity in homes that the user has chosen not to sell) if either the household head, her spouse/partner, or both live to their maximum ages of life.

The amount of recommended consumption expenditures needed to achieve a given living standard varies from year to year in response to changes in the household's composition. Moreover, the relationship between consumption and living standard in a given year is non-linear for two reasons. First, a non-linear function governs the program's assumed economies of shared living, with the function depending on the number of equivalent adults. Second, the program permits users to specify that children are less or more expensive than adults in terms of delivering a given living standard. The default setting is that a child is 70 percent as expensive as an adult. Hence a household with 2 adults and 2 children is specified, under the default assumptions, to entail 4 equivalent adults.

The program's recommended consumption also rises when the household moves from a situation of being liquidity constrained to one of being unconstrained. Finally, recommended household consumption will change over time if users intentionally specify, via the program's standard of living index, that they want their living standard to change.

The simultaneity issue with respect to taxes mentioned above is just one of two such issues that need to be considered. The second is the joint determination of life insurance holdings of potential decedents and survivors. ESPlanner recognizes that widows and widowers may need to hold life insurance in order to protect their children's living standard through adulthood and to cover bequests, funeral expenses, and debts (including mortgages) that exceed the survivor's net worth inclusive of the equity on her/his house. Accordingly, the software calculates these life insurance requirements and reports them in its survivor reports.

However, the more life insurance is purchased by the potential decedent, the less life insurance survivors will need to purchase, assuming they have such a need. But this means survivors will pay less in life insurance premiums and have less need for insurance protection from their decedent spouse/partner. Hence, one can't determine the potential decedent's life insurance holdings until one determines the survivor's holdings. But one can't determine the survivor's holdings until one determines the decedent's holdings. 
Dealing with the tax and life insurance simultaneity issues as well as the borrowing and nonnegative life insurance constraints all within a single dynamic program appears impossible given the large number of state variables such an approach entails. To overcome this problem, ESPlanner uses an iterative method of dynamic programming. Specifically, the program has two dynamic programs that pass data to one another on an iterative basis until they both converge to a single mutually consistent solution to many decimal points of accuracy.

One program takes age-specific life insurance premium payments as given and calculates the household's consumption smoothing conditional on these payments. The other program takes the output of this consumption smoothing program -- the living standard in each year that needs to be protected - as given. This second program calculates how much life insurance is needed by both potential decedents and their surviving spouses/partners.

This iterative procedure also deals with our two simultaneity issues. The trick here is to form initial guesses of future taxes and survivor life insurance holdings and update these guesses across successive iterations based on values of these variables endogenously generated by the program in the previous iteration. When the program concludes its calculations, current spending is fully consistent with future taxes and vice versa, and the recommended life insurance holdings of heads and spouses/partners are fully consistent with the recommended life insurance holdings of survivors.

\section{The Living Standard Impacts of Social Security Benefit Cuts -- Stylized Households}

This section examines the costs in terms of living standard reductions of Social Security benefit cuts for a set of 14 stylized households. The 14 households differ with respect to their marital status, annual labor earnings, assets, housing expenses, and college expenses. For each household, we consider the impact of the benefit cuts arising unexpectedly at three different points in their life cycle - when the household head and, if married, spouse are age 35, age 50, and age 65 .

\section{Characteristics of Our Stylized Households}

To determine each household's asset levels at ages 35, 50, and 65, we first run ESPlanner with no benefit cuts. Specifically, we run the program for each stylized household specifying the age of the household head and, in the case of married households, the spouse as age 35 . In this initial run we specify the presence of two children ages 1 and 3. We also enter age-35 asset levels, housing expenses, including the annual payment on a 30-year mortgage, initial earnings, and annual college expenses when the children are ages 19 to 22 . Finally, we assume that the households' labor earnings remain fixed in real dollars through time, that the households earns a 3 percent real (over and above inflation) pre-tax return on its investments, and that the husband and wife both have maximum ages of life equal to 100 .

Table 1 reports the characteristics of our stylized households as of age 35. Take, as an example, the single household with annual earnings of $\$ 50,000$. We assume initial age-35 asset holdings equal $\$ 12,500$. We also assume annual college expenditures of $\$ 12,500$ per child, a $\$ 120,000$ outstanding mortgage with a $\$ 1,500$ monthly payment, $\$ 1,500$ in annual property taxes, and 
$\$ 750$ in annual home maintenance expenses. With the exception of our $\$ 50,000$ upper bound on annual college expenses, the non-earnings entries for the other households are scaled by their levels of earnings; e.g., the single and married households with $\$ 100,000$ in annual earnings have initial assets at age 35 of $\$ 25,000$, which is twice the initial assets of the single and married households earning $\$ 50,000$ per year.

Continuing with the example of the single age-35 household earning $\$ 50,000$, we extract the asset levels, remaining mortgage balance and length of mortgage, and remaining college expenditures for this household at ages 35,50, and 65. We then use these values as inputs in three separate ESPlanner runs for this household at those three ages. In these separate runs we specify, alternatively, no Social Security benefit cut, a 30 percent cut, and a 100 percent cut. In following this procedure we are, in effect, treating the cuts as being a surprise at the time they are announced. We are also holding as much constant as possible in comparing by age the living standard adjustments to benefit cuts.

\section{Illustrating Our Findings}

Tables 2-4 show results from our age-35 runs under the three alternative benefit cut assumptions. Specifically, the tables show the levels of consumption, regular assets, and taxes at ages 35, 50, and 65. Tables 5-7 show results from our age-50 runs, displaying consumption, asset, and tax values at ages 50 and 65 . And tables 8-10 show results from our age-65 run, displaying consumption, asset, and tax values only at age 65 .

Take, as an example, the married age-35 household earning $\$ 30,000$. Table 2, which assumes no benefit cut, shows the household will consume $\$ 16,751$ at age $35, \$ 11,689$ at age 50, and $\$ 18,145$ at age 65 . The explanation for the lower value of consumption at age 50 is that the children have left the household. The explanation for the higher value of consumption at age 65 than at age 50 is that the household is borrowing constrained until its late 50s when the kids have been put through college and the mortgage has been paid off. As indicated in the table, the household accumulates very little by way of retirement assets. This makes sense since the household's Social Security benefits are considerable relative to its household's pre-retirement consumption expenditure level.

How does this household respond to a 30 percent cut in its future Social Security benefits if it learns about the benefit cut at age 35? The answer, according to table 3 , is that the household continues to spend essentially the same amount it was spending while young and middle age, but that it begins saving more in its late 50s and early 60s to mitigate the reduction in Social Security income, which begins at age 65 . Indeed, by age 65 the household has $\$ 50,194$ in assets compared with only $\$ 5,435$ in the case of no benefit cut.

Consider next what happens if this household learns at age 35 not of a 30 percent benefit cut, but of a 100 percent benefit cut. In this case the household moves from being liquidity constrained to being unconstrained and realizes that it will need to cut its current consumption if it wants to have as high a living standard in old age as it has when young. As a comparison of tables 2 and 3 indicate, totally eliminating Social Security benefits engenders a 23.5 percent reduction in 
living standards at ages 35 and 50 and a 50.7 percent reduction at age 65 . These figures are, by the way, reported in table 11.

Here again we see the critical role of saving responses in determining the ultimate living standard impact of cutting Social Security - even for households doing little or no initial saving. Indeed, at age 65 this household that would otherwise have saved only $\$ 5,435$ in assets. When Social Security benefits are eliminated, it ends up accumulating \$224,144 by 65 .

\section{The Importance of Advanced Warning}

Learning early that one's benefits are to be cut can make a big difference to a household's consumption-saving response and to the associated retirement living standard reductions. This is evident once one compares tables 11,12 , and 13, which show the percentage reduction in agespecific living standards contingent on learning about the future benefit cuts at ages 35,50 , and 65 , respectively.

In the case of the $\$ 30,000$-earning married couple facing a 30 percent benefit cut, the retirement living standard declines by 17.8 percent if the household first learns about the cut at age 35, 23.3 percent if the household first learns at age 50, and 32.2 percent if the household first learns at age 65 . $^{2}$ Note that the 32.2 percent retirement living standard decline is almost twice as large as the 17.8 percent decline.

The 100 percent benefit cut generates equally striking differences in retirement living standard reductions depending on when the household learns about the cut. For our household in question, learning at ages 35, 50, and 65 about losing its benefits leads to respective retirement living standard reductions of 50.7 percent, 67.5 percent, and 100 percent.

Clearly, in delaying notification of this household that its benefits are to be cut, the government is giving the household less time to adjust by altering its saving. The upshot is a distortion in the life-cycle pattern of consumption. Gomes, Kotlikoff, and Viceira (2006) discuss this distortion, which they refer to as the "excess burden of government indecision," and show that it can be economically significant.

\section{Patterns by Marital Status, Age of Learning and Earnings Levels}

Tables 11-13 indicate some interesting patterns by marital status, age of learning about the cut, and earnings in the living standard responses to benefit cuts. First, controlling for total household earnings the results for singles and married households are, broadly speaking, very similar. Second, as suggested above, when the household learns its benefits are to be cut matters a lot to its immediate living standard. Take the 30 percent cut. Across all earnings levels there is essentially no change in current living standards whether the household first learns at age 35 or at

\footnotetext{
2 The fact that the last figure - 32.2 percent - exceeds 30 percent can be understood by noting that while this household's primary income source has declined by 30 percent, its fixed housing expenses (property taxes, homeowners insurance, and maintenance) have not declined at all. Hence, the percentage decline in consumable resources is actually greater than 30 percent.
} 
age 50. But there is a sizeable drop in the current living standard if the household first learns at age 65 of the 30 percent cut.

The fact that benefit cuts, even as large as 30 percent, make so little difference to immediate consumption of our young and middle-aged stylized household is testimony to the importance of the liquidity constraints facing these households. On the other hand, if the cuts are large enough, they will affect immediate as well as future living standards even at younger ages. Tables 11 and 12 shows that if households learn at either age 35 or age 50 that their benefits will be eliminated, their current living standards fall by 18 to 28 percent, depending on their income, if they are initially age 30 and by roughly 32 to 43 percent, depending on income, if they are initially age 50. There are some non-linear living standard reductions in tables 11 and 12. These reflect different degrees and timing of liquidity constraints among the households as well as nonlinearities in income taxes.

Retirement living standards do, of course, respond substantially to the 30 percent benefit cut. But the size of the response depends significantly on the household's income and the timing of the benefit cut announcement. If the 30 percent cut is first learned at age 30, retirement living standards will fall by roughly one quarter for the lowest earning of our stylized households and roughly 5 percent for the highest earning. If it is first learned at age 65, the living standard reduction ranges from 32 percent for the lowest earning households to 11 percent for the lowest earning households.

The largest living standard reductions occur, of course, in the case the benefit cut is 100 percent and is announced when the household is age 65. In this case, the retirement living standard reductions range from 100 percent to roughly 35 percent as one moves from the lowest to the highest earning households.

The highest earning households, in table 13 , are married households with $\$ 500,000$ in annual earnings. The fact that such households would suffer a 35 percent living standard reduction were Social Security entirely eliminated at their point of retirement is quite striking. If correct, this finding suggests that like low- and middle-income households, high-income households have a major stake in preserving Social Security benefits.

But how can it be that such a high-earning household could be so vulnerable to Social Security benefit cuts announced at the point of retirement? It's not for a lack of saving. The $\$ 500,000$ earning married couple arrives at age 65 with $\$ 2.3$ million in assets. That seems like a lot of money. But the pre-tax real return the household earns on these assets is only 3 percent, and it has a potential retirement of 35 years to finance. By way of reference, 3 percent of $\$ 2.3$ million is just $\$ 69,000$ per year. Of course the household will consume not just principal, but also interest on its $\$ 2.3$ million. But spending principal plus interest generates an annual income flow of just $\$ 107,040$. This is larger than it may seem because the household pays taxes on the interest and also faces $\$ 22,500$ in off-the-top housing expenses. Taxes at age 65 are $\$ 38,793$. They decline, of course, through time as the household runs down its assets and generates less taxable asset income. But midway through retirement, at age 82, they are still quite high, in this case $\$ 20,904$. 
If one subtracts, say, $\$ 20,000$ in taxes and $\$ 22,500$ in housing expenses from the annual income flow of $\$ 107,040$, what's left for the household to spend on consumption is $\$ 64,540$. From this perspective, the household's combined $\$ 47,434$ in annual Social Security benefits looms quite large. Of course these benefits are, themselves, subject to federal income taxation, so they too need to be considered on an after-tax basis. But these figures are enough to paint the picture. They make clear why eliminating Social Security benefits for this household on the brink of its retirement could easily reduce its sustainable living standard by 35.6 percent - the figure reported in table 13 .

\section{The 2004 Survey of Consumer Finance Data}

We now turn to the evaluation of the living standard costs of Social Security benefit cuts based on actual households surveyed in the 2004 Survey of Consumer Finances (SCF). The SCF is sponsored by the Federal Reserve Board in cooperation with the Department of the Treasury. Since 1992, data have been collected by the National Organization for Research at the University of Chicago (NORC). The SCF is conducted every three years and gathers detailed information on the demographics, incomes, assets, and other financial characteristics of U.S. families. No other U.S. data set collects financial data of similar quality.

The 2004 SCF surveyed 4,519 households selected from all economic strata. In the SCF, a household unit is divided into a "primary economic unit" (PEU) - the family — and everyone else in the household. The PEU is intended to be the economically dominant single individual or couple (whether married or living together as partners) and all other persons in the household who are financially interdependent with that economically dominant person or couple.

In this study, we restrict attention to only those observations in which the number of household members coincides with the number of people in the PEU. This sample selection criterion eliminates 434 observations (9.5 percent) from the sample.

The SCF incorporates 86 different marital status categorizations based on the participation of the spouse/partner in the PEU and the actual presence of the spouse/partner in the household. We include household with one of the following marital statuses: 1) "married, spouse usually there, spouse in PEU"; 2) "living with a partner, partner in PEU, partner usually there"; 3) "separated and currently single"; 4) "divorced/widowed and currently single", and 5) "single". Restricting our sample to households with one of these four statuses further reduces our sample size, in this case by 77 observations (1.5 percent).

Finally, we considered only households whose heads are 25 and above. This further reduced our sample by 140 observations. After applying these sample selections, we arrived at a set of 3690 observations, i.e. a reduction of about 18 percent. From these observations, we choose 200 at random, which we entered by hand in ESPlanner. We entered each observation by hand to ensure that each of the inputs for a given household made complete sense; i.e., did not represent unreasonable survey responses or extreme outliers. In the course of arriving at our final 200 cases, we eliminated 3 observations. 
Although our 200 observations constitute a random subsample of our selected SCF sample, they don't represent a random sample of U.S. households. The reason is that the SCF overweights high income and high net worth households. To adjust for this fact we applied the SCF's household sample weights in calculating the distributions of living standard reductions arising from 30 percent and 100 percent benefit cuts.

\section{Imputations}

The ages of respondents' children are not reported in the SCF for privacy reason. Since these ages are critical inputs into ESPlanner, we developed the following imputation strategy. We assume children leave the PEU when they turn 19. The age of each child is computed as the difference between the actual age of the youngest parent and the mean age of the mother at given number of births obtained from the "National Vital Statistics Report" (volume 51, number 1). The mean age of the mother is differentiated by the birth order of the child.

Other than demographic information, we collect data on labor earnings, special expenditure and receipts, life insurance, financial assets, retirement accounts, pensions (current and future), primary residence, property taxes, mortgages and social security. Labor earnings are differentiated by head and spouse/partner as well as whether, in her primary job, the respondent is an employee or self-employed. Earnings in secondary jobs reported by respondents are treated as coming from employment as opposed to self-employment since the SCF does not indicate otherwise. In addition to these procedures, we assume zero growth of real earnings in the future.

In most cases, respondents reported their lengths of mortgages in addition to their monthly payments and outstanding balances. In those cases where the length of a mortgage was not reported, we assumed a 7 percent mortgage rate and used the monthly payment and outstanding balance to infer the length of the mortgage.

We set the retirement age of a respondent or spouse/partner at the age she indicates she will stop working altogether. If she indicates no plans to stop working, we assume she retires at 70 or at their current age plus 1 , whichever is greater.

Regular assets are formed by adding together the household's reported holdings of stocks, bonds, checking accounts, saving accounts, and other financial instruments. For retirement accounts we collect data on the account balance, the amount of last year's contributions, and the expected age at first withdraw. The accounts are grouped in four categories, namely Keogh and SEP plans, various IRA plans, Roth IRA and others. The category "others" includes all remaining defined contribution retirement schemes such as 401(k), 403(b), supplementary retirement annuity, Thrift plans, profit sharing plans and mixed (defined benefits-defined contributions) plans. These groupings reflect the structure of the dataset and the requirements of ESPlanner.

The expected age at first withdraw may differ according to the retirement account. Since ESPlanner assumes a single age at which all accounts are withdrawn, we use the expected age connected to the largest account. However, if the household is already withdrawing money from one of her accounts, we set the age at first withdraw equal to the current age. 
In the case of pensions, we collect data on each spouse's/partner's benefits, either those currently being received or those expected to be received. The SCF reports information on up to three defined benefit schemes for each spouse/partner. Data on indexation and survivor percentage are limited. Consequently, when not reported, we assume no indexation of pension benefits and a 50 percent survivor's benefit.

For respondents currently receiving social security benefits, we use the respondents' reported benefit start date and monthly payment. For households not currently collecting benefits, we assume that all future employee earnings are covered by Social Security.

Past employment and self-employment earnings are also assumed to be covered by social security. However, we do not have data on past covered earnings. Therefore, we assume respondents started working at age 25 and that their earnings grew every year at a 5 percent nominal growth rate, ending up in the current year at their reported current earnings levels.

\section{The Living Standard Impacts of Social Security Benefit Cuts -- SCF Households}

After inputting our SCF data into ESPlanner, we ran the program specifying no benefit cuts and then twice again, specifying cuts of 30 percent and 100 percent. Tables 14 and 15 present summary statistics with respect to the derived immediate and age-65 living standard changes generated by our sample. The statistics in these tables are un-weighted. The subsequent distribution tables employ household weights.

Table 14 shows that average and median immediate living standard changes are much larger for older households as our analysis of the stylized households leads one to expect. In the case of a 30 percent benefit cut, the median immediate reduction is 13.8 percent versus 2.1 percent for respondents age 25-44. With a 100 percent cut, the median reductions range from 13.0 percent for the 25-44 respondents to 43.0 percent for the $65+$ respondents.

The medians in table 15, which considers living standard reductions at age 65 for young and middle aged households, are much larger than in table 14. For example, with a 100 percent benefit cut, the median living standard reduction at age 65 for respondents age 25-44 is 30.7 percent - much higher than the median 13.0 percent immediate living standard reduction reported for this age group in table 14.

This is what one would expect given the borrowing constraints facing young and middle aged households in our sample. In our sample, 62.3 percent of households age 25-44 are liquidity constrained, 25.8 percent of households age 45-64 are constrained, and 8.8 percent of households age 65 and over are constrained.

There is considerable variation within each age group with respect to the living standard reductions. The medians differ substantially from the means, and there is a wide range between mean vales and the minimum and maximum values. The minimum values indicate that Social Security benefit cuts can raise living standards for some households. The explanation here is that the future benefit cuts lower the household head's and, if married or partnered, her 
spouse's/partner's future income and, potentially, the need for life insurance to protect survivors' living standards. In paying less life insurance premiums, such households end up with more cash to finance a higher current living standard.

Tables 16-19 and figures 1-8 display distributions of immediate and, in the case of young and middle aged households, age-65 living standard reductions by the age of the household head and the size of the living standard reduction.

To begin, consider figures 1 and 2, which plot the data in table 16. Figure 1 applies to singles and figure 2 to couples, whether married or partnered. Both figures show the percentage of households in age groups with heads age 25-44, 45-64, and 65 plus experiencing different percentage reductions in their immediate living standards resulting from a 30 percent cut in Social Security benefits.

Young households, whether single or married, experience very small immediate living standard declines. Indeed, 79 percent of single young households and 98 percent of married/partnered young households experience a decline of 10 percent or less, reflecting the fact that most of these households are liquidity constrained. Middle aged households experience slightly larger, but still quite small immediate living standard reductions from the 30 percent benefit cut. In contrast, older households, particularly older single households, are adversely affected to a significant degree. A full third of older households experience immediate living standard reductions of 30 percent or more. Among single (coupled) older households, 8 percent experience living standard reductions of 40 to 50 (50 to 60$)$ percent.

Figures 3 and 4, based on table 17, repeat this analysis, but consider 100 percent benefit cuts. As we saw among the stylized households, losing so much of one's future income loosens liquidity constraints, not because households can now freely borrow against their future income, but because they no longer seek to borrow. As they see their future incomes fall, large numbers of the households in our sample realize they must significantly increase their current saving and lower their current consumption spending, often dramatically. This is true for almost all older households as well as many middle-aged and younger ones.

The percentages of older singles and couples experiencing 90 percent or greater immediate living standard reductions are 33 percent and 41 percent, respectively. The percentages of older singles and couples experiencing 50 percent or greater living standard reductions are 52 percent and 58 percent, respectively. Clearly, the elderly in the SCF are highly dependent on Social Security benefits.

Among the middle aged, some 61 percent of couples and 32 percent of singles would be forced to cut their living standards by 30 percent or more in response to the announced elimination of Social Security benefits. The corresponding figures for young couples and singles are 10 percent and 31 percent, respectively.

Figures 5 and 6 based on table 18 shows how the living standards at age 65 of current young and middle-aged households would be affected by a 30 percent benefit cut. The finding here is that close to half of all these households would experience a 10-20 percent living standard reduction. 
These reductions in age-65 living standard are modest compared to those shown in figures 7 and 8 (based on table 19) in which the total elimination of Social Security benefits is contemplated. Under this draconian cut, large fractions of young and middle age households experience living standard reductions at age 65 and thereafter that range from 20 to 60 percent. For example, 89 percent of couples age 45-64 experience living standard cuts of 20 percent or more; and 36 percent experience cuts of 40 percent or more.

\section{Regression Analysis of Determinants of Living Standard Reductions}

To more fully understand the determinants of living standard reductions, we regress the percentage change in immediate and age-65 living standards arising from 30 percent and 100 percent benefit cuts against marital status (single or couple), age of the head, the ratio of the household's current living standard before the cut to the average living standard in the sample, the square of this ratio, and a dummy variable that takes the value one if the household is liquidity constrained.

The results are presented in table 18. Consider the first two columns in which the dependent variable is the reduction in immediate living standards from 30 percent and 100 percent benefit cuts. Apart from marital status and the squared relative living standard ratio, all regressors are significant. Older households experience larger reductions. Liquidity constrained households experience smaller reductions. So do households with higher current living standards relative to the average. The results in the last two columns, in which the living standard reduction at 65 is the dependent variable, display similar signed coefficients.

\section{Conclusion}

Understanding the living standard implications for working and retired households of cutting Social Security benefits requires more than simply considering the size of these benefits relative to other resources. One needs to understand how Social Security benefits and other resources stocks and flows combine to determine a household's living standard time path in light of taxes and borrowing constraints. This study uses ESPlanner to determine households' smoothest living standard paths assuming zero borrowing for purposes of consumption smoothing. It then examines how the living standards of both stylized households and households surveyed in the 2004 Survey of Consumer Finances would respond to 30 percent and 100 percent benefit cuts.

The findings indicate that the vast majority of today's elderly, even those with very high levels of past earnings and large asset holdings, would experience very major living standard reductions from such cuts. Younger and middle aged households would be less affected in the short run by a 30 percent cut, since they are largely liquidity constrained. But such a cut would materially alter their living standard in retirement. The full elimination of Social Security benefits would, on the other hand, significantly reduce the current as well as the future living standards of today's young and middle-aged households as well as dramatically reduce the living standards of most current elderly. 


\section{References}

Gokhale, Jagadeesh and Kent Smetters, "Measuring Social Security's Financial Problems," NBER working paper no. 11060, January 2005.

Gomes, Francisco, Laurence J. Kotlikoff, and Luis Viceira, "The Excess Burden of Government Indecision," mimeo Boston University, 2006 
Table 1

Characteristics of Our Stylized Households

\begin{tabular}{|c|c|c|c|c|c|c|c|}
\hline \multicolumn{8}{|c|}{ Single Households } \\
\hline $\begin{array}{c}\text { Total } \\
\text { Household } \\
\text { Income }\end{array}$ & $\begin{array}{c}\text { Assets } \\
\text { at Age } \\
30\end{array}$ & $\begin{array}{c}\text { Annual } \\
\text { College } \\
\text { Expense }\end{array}$ & $\begin{array}{l}\text { House } \\
\text { Value }\end{array}$ & Mortgage & $\begin{array}{c}\text { Monthly } \\
\text { Mortgage } \\
\text { Payment }\end{array}$ & $\begin{array}{c}\text { Annual } \\
\text { Property } \\
\text { Taxes }\end{array}$ & $\begin{array}{l}\text { Annual Home } \\
\text { Maintenance }\end{array}$ \\
\hline$\$ 10,000$ & $\$ 2,500$ & $\$ 2,500$ & $\$ 30,000$ & $\$ 24,000$ & $\$ 300$ & $\$ 300$ & $\$ 150$ \\
\hline$\$ 15,000$ & $\$ 3,750$ & $\$ 3,750$ & $\$ 45,000$ & $\$ 36,000$ & $\$ 450$ & $\$ 450$ & $\$ 225$ \\
\hline$\$ 25,000$ & $\$ 6,250$ & $\$ 6,250$ & $\$ 75,000$ & $\$ 60,000$ & $\$ 750$ & $\$ 750$ & $\$ 375$ \\
\hline$\$ 35,000$ & $\$ 8,750$ & $\$ 8,750$ & $\$ 105,000$ & $\$ 84,000$ & $\$ 1,050$ & $\$ 1,050$ & $\$ 525$ \\
\hline$\$ 50,000$ & $\$ 12,500$ & $\$ 12,500$ & $\$ 150,000$ & $\$ 120,000$ & $\$ 1,500$ & $\$ 1,500$ & $\$ 750$ \\
\hline$\$ 100,000$ & $\$ 25,000$ & $\$ 25,000$ & $\$ 300,000$ & $\$ 240,000$ & $\$ 3,000$ & $\$ 3,000$ & $\$ 1,500$ \\
\hline$\$ 250,000$ & $\$ 62,500$ & $\$ 50,000$ & $\$ 750,000$ & $\$ 600,000$ & $\$ 7,500$ & $\$ 7,500$ & $\$ 3,750$ \\
\hline \multicolumn{8}{|c|}{ Married Households } \\
\hline $\begin{array}{c}\text { Total } \\
\text { Household } \\
\text { Income }\end{array}$ & $\begin{array}{c}\text { Assets } \\
\text { at Age } \\
30\end{array}$ & $\begin{array}{c}\text { Annual } \\
\text { College } \\
\text { Expense }\end{array}$ & $\begin{array}{l}\text { House } \\
\text { Value }\end{array}$ & Mortgage & $\begin{array}{c}\text { Monthly } \\
\text { Mortgage } \\
\text { Payment }\end{array}$ & $\begin{array}{c}\text { Annual } \\
\text { Property } \\
\text { Taxes } \\
\end{array}$ & $\begin{array}{c}\text { Annual } \\
\text { Home } \\
\text { Maintenance }\end{array}$ \\
\hline$\$ 20,000$ & $\$ 5,000$ & $\$ 5,000$ & $\$ 60,000$ & $\$ 48,000$ & $\$ 600$ & $\$ 600$ & $\$ 300$ \\
\hline$\$ 30,000$ & $\$ 7,500$ & $\$ 7,500$ & $\$ 90,000$ & $\$ 72,000$ & $\$ 900$ & $\$ 900$ & $\$ 450$ \\
\hline$\$ 50,000$ & $\$ 12,500$ & $\$ 12,500$ & $\$ 150,000$ & $\$ 120,000$ & $\$ 1,500$ & $\$ 1,500$ & $\$ 750$ \\
\hline$\$ 70,000$ & $\$ 17,500$ & $\$ 17,500$ & $\$ 210,000$ & $\$ 168,000$ & $\$ 2,100$ & $\$ 2,100$ & $\$ 1,050$ \\
\hline$\$ 100,000$ & $\$ 25,000$ & $\$ 25,000$ & $\$ 300,000$ & $\$ 240,000$ & $\$ 3,000$ & $\$ 3,000$ & $\$ 1,500$ \\
\hline$\$ 200,000$ & $\$ 50,000$ & $\$ 50,000$ & $\$ 600,000$ & $\$ 480,000$ & $\$ 6,000$ & $\$ 6,000$ & $\$ 3,000$ \\
\hline$\$ 500,000$ & $\$ 125,000$ & $\$ 50,000$ & $\$ 1,500,000$ & $\$ 1,200,000$ & $\$ 15,000$ & $\$ 15,000$ & $\$ 7,500$ \\
\hline
\end{tabular}


Table 2

Consumption, Assets, and Taxes of Age 35 Households Experiencing No Benefit Cuts

\begin{tabular}{|c|c|c|c|c|c|c|c|c|c|}
\hline \multicolumn{10}{|c|}{ Single, Age 35 Households Experiencing No Benefit Cut } \\
\hline \multirow{2}{*}{$\begin{array}{c}\text { Total } \\
\text { Household } \\
\text { Income }\end{array}$} & \multicolumn{3}{|c|}{ Consumption (\$) } & \multicolumn{3}{|c|}{ Regular Assets (\$) } & \multicolumn{3}{|c|}{ Taxes (\$) } \\
\hline & Age 35 & Age 50 & Age 65 & Age 35 & Age 50 & Age 65 & Age 35 & Age 50 & Age 65 \\
\hline$\$ 10,000$ & 9,172 & 5,066 & 8,576 & 2,707 & 942 & 0 & $(3,235)$ & 770 & 0 \\
\hline$\$ 15,000$ & 12,119 & 6,693 & 10,099 & 4,089 & 1,340 & 2 & $(3,233)$ & 1,992 & 0 \\
\hline$\$ 25,000$ & 15,067 & 8,322 & 13,338 & 6,363 & 265 & 21,598 & 224 & 4,102 & 0 \\
\hline$\$ 35,000$ & 18,342 & 10,652 & 17,776 & 8,718 & 0 & 38,634 & 3,271 & 6,136 & 0 \\
\hline$\$ 50,000$ & 24,918 & 14,633 & 23,081 & 12,604 & 0 & 71,759 & 5,814 & 9,350 & 868 \\
\hline$\$ 100,000$ & 42,456 & 24,821 & 33,561 & 25,019 & 0 & 246,572 & 19,229 & 23,144 & 4,573 \\
\hline$\$ 250,000$ & 100,414 & 55,460 & 55,460 & 61,138 & 84,894 & $1,010,471$ & 55,264 & 62,515 & 17,343 \\
\hline \multicolumn{10}{|c|}{ Married, Age 35 Households Experiencing No Benefit Cut } \\
\hline \multirow{2}{*}{$\begin{array}{c}\text { Total } \\
\text { Household } \\
\text { Income }\end{array}$} & \multicolumn{3}{|c|}{ Consumption (\$) } & \multicolumn{3}{|c|}{ Regular Assets (\$) } & \multicolumn{3}{|c|}{ Taxes (\$) } \\
\hline & Age 35 & Age 50 & Age 65 & Age 35 & Age 50 & Age 65 & Age 35 & Age 50 & $\begin{array}{c}\text { Age } \\
65\end{array}$ \\
\hline$\$ 20,000$ & 13,405 & 9,354 & 15,279 & 5,827 & 2,280 & 901 & $(1,822)$ & 2,247 & 0 \\
\hline$\$ 30,000$ & 16,751 & 11,689 & 18,145 & 8,363 & 1,886 & 5,435 & 1,002 & 4,161 & 0 \\
\hline$\$ 50,000$ & 24,544 & 17,127 & 25,644 & 13,800 & 2,162 & 44,732 & 5,051 & 8,305 & 0 \\
\hline$\$ 70,000$ & 32,719 & 22,832 & 33,042 & 19,145 & 2,460 & 91,589 & 8,815 & 12,226 & 834 \\
\hline$\$ 100,000$ & 43,860 & 30,606 & 43,276 & 27,067 & 3,253 & 154,035 & 15,657 & 19,314 & 2,972 \\
\hline$\$ 200,000$ & 74,508 & 51,992 & 64,938 & 54,294 & 6,531 & 458,719 & 44,084 & 47,891 & 8,898 \\
\hline$\$ 500,000$ & 169,301 & 118,140 & 118,140 & 136,651 & 602,315 & $2,194,396$ & 125,907 & 143,045 & 40,797 \\
\hline
\end{tabular}


Table 3

Consumption, Assets, and Taxes of Age 35 Households

Assuming a 30 Percent Benefit Cut

Single, Age 35 Households Assuming a 30\% Benefit Cut

\begin{tabular}{|c|c|c|c|c|c|c|c|c|c|}
\hline \multirow{2}{*}{$\begin{array}{c}\text { Total } \\
\text { Household } \\
\text { Income }\end{array}$} & \multicolumn{3}{|c|}{ Consumption (\$) } & \multicolumn{3}{c|}{ Regular Assets (\$) } & \multicolumn{3}{c|}{ Taxes (\$) } \\
\cline { 2 - 10 } & Age 35 & Age 50 & Age 65 & Age 35 & Age 50 & Age 65 & Age 35 & Age 50 & Age 65 \\
\hline 10,000 & 9,167 & 5,063 & 6,308 & 2,709 & 939 & 9,560 & $(3,235)$ & 781 & 0 \\
$\$ 15,000$ & 12,122 & 6,689 & 7,965 & 4,093 & 1,336 & 23,901 & $(3,233)$ & 1,992 & 0 \\
$\$ 25,000$ & 15,059 & 8,317 & 10,889 & 6,367 & 261 & 56,496 & 224 & 4,102 & 38 \\
$\$ 35,000$ & 18,331 & 10,652 & 14,622 & 8,724 & 0 & 83,334 & 3,271 & 6,136 & 23 \\
$\$ 50,000$ & 24,904 & 14,633 & 19,008 & 12,612 & 0 & 127,641 & 5,814 & 9,350 & 911 \\
$\$ 100,000$ & 42,435 & 24,821 & 28,400 & 25,031 & 0 & 316,695 & 19,229 & 23,144 & 4,046 \\
$\$ 250,000$ & 95,179 & 52,569 & 52,569 & 66,402 & 166,572 & $1,139,858$ & 55,264 & 64,268 & 17,553 \\
\hline
\end{tabular}

Married, Age 35 Households Assuming a 30\% Benefit Cut

\begin{tabular}{|c|c|c|c|c|c|c|c|c|c|}
\hline \multirow{2}{*}{$\begin{array}{c}\text { Total } \\
\text { Household } \\
\text { Income }\end{array}$} & \multicolumn{3}{|c|}{ Consumption (\$) } & \multicolumn{3}{c|}{ Regular Assets (\$) } & \multicolumn{3}{c|}{ Taxes (\$) } \\
\cline { 2 - 10 } & Age 35 & Age 50 & Age 65 & Age 35 & Age 50 & Age 65 & Age 35 & Age 50 & $\begin{array}{c}\text { Age } \\
\mathbf{6 5}\end{array}$ \\
\hline 20,000 & 13,357 & 9,321 & 11,429 & 5,848 & 2,237 & 18,794 & $(1,822)$ & 2,246 & 0 \\
$\$ 30,000$ & 16,671 & 11,633 & 14,922 & 8,339 & 1,845 & 50,194 & 1,002 & 4,161 & 0 \\
$\$ 50,000$ & 24,444 & 17,057 & 21,477 & 13,755 & 2,117 & 105,809 & 5,051 & 8,304 & 0 \\
$\$ 70,000$ & 32,582 & 22,736 & 27,782 & 19,103 & 2,423 & 167,303 & 8,815 & 12,226 & 934 \\
$\$ 100,000$ & 43,710 & 30,502 & 36,481 & 27,043 & 3,231 & 248,183 & 15,657 & 19,314 & 2,849 \\
$\$ 200,000$ & 74,402 & 51,919 & 55,099 & 54,205 & 6,399 & 597,071 & 44,084 & 47,886 & 8,124 \\
$\$ 500,000$ & 160,313 & 111,868 & 111,868 & 145,463 & 743,739 & $2,492,573$ & 135,907 & 146,135 & 41,136 \\
\hline
\end{tabular}


Table 4

Consumption, Assets, and Taxes of Age 35 Households

Assuming a 100 Percent Benefit Cut

Single, Age 35 Households Assuming a 100\% Benefit Cut

\begin{tabular}{|c|c|c|c|c|c|c|c|c|c|}
\hline \multirow{2}{*}{$\begin{array}{c}\text { Total } \\
\text { Household } \\
\text { Income }\end{array}$} & \multicolumn{3}{|c|}{ Consumption (\$) } & \multicolumn{3}{c|}{ Regular Assets (\$) } & \multicolumn{3}{c|}{ Taxes (\$) } \\
\cline { 2 - 10 } & Age 35 & Age 50 & Age 65 & Age 35 & Age 50 & Age 65 & Age 35 & Age 50 & Age 65 \\
$\$ 10,000$ & 6,736 & 3,720 & 3,720 & 4,896 & 38,538 & 92,129 & $(2,977)$ & $(2,878)$ & 125 \\
$\$ 15,000$ & 9,187 & 5,074 & 5,074 & 7,031 & 46,840 & 125,129 & $(3,233)$ & 2,435 & 0 \\
$\$ 25,000$ & 12,465 & 6,884 & 6,884 & 9,225 & 44,916 & 174,502 & $(30)$ & 4,491 & 112 \\
$\$ 35,000$ & 15,645 & 8,641 & 8,641 & 11,417 & 44,998 & 225,232 & 3,271 & 6,594 & 481 \\
$\$ 50,000$ & 20,966 & 11,580 & 11,580 & 16,564 & 66,511 & 311,457 & 5,814 & 10,209 & 1,283 \\
$\$ 100,000$ & 35,516 & 19,616 & 19,616 & 31,981 & 112,261 & 569,986 & 19,229 & 24,963 & 4,225 \\
$\$ 250,000$ & 82,786 & 45,724 & 45,724 & 78,867 & 358,663 & $1,445,060$ & 55,264 & 68,385 & 18,166 \\
\hline
\end{tabular}

Married, Age 35 Households Assuming a 100\% Benefit Cut

\begin{tabular}{|c|c|c|c|c|c|c|c|c|c|}
\hline \multirow{2}{*}{$\begin{array}{c}\text { Total } \\
\text { Household } \\
\text { Income }\end{array}$} & \multicolumn{3}{|c|}{ Consumption (\$) } & \multicolumn{3}{c|}{ Regular Assets (\$) } & \multicolumn{3}{c|}{ Taxes (\$) } \\
\cline { 2 - 10 } & Age 35 & Age 50 & Age 65 & Age 35 & Age 50 & Age 65 & Age 35 & Age 50 & $\begin{array}{c}\text { Age } \\
\mathbf{6 5}\end{array}$ \\
\hline 20,000 & 9,487 & 6,620 & 6,620 & 9,514 & 53,884 & 165,826 & $(1,822)$ & 2,650 & 206 \\
$\$ 30,000$ & 12,820 & 8,946 & 8,946 & 11,983 & 62,675 & 224,144 & 1,002 & 4,748 & 25 \\
$\$ 50,000$ & 19,341 & 13,496 & 13,496 & 18,649 & 89,617 & 344,838 & 5,051 & 9,272 & 406 \\
$\$ 70,000$ & 25,509 & 17,800 & 17,800 & 25,958 & 123,991 & 474,728 & 8,815 & 13,505 & 1,951 \\
$\$ 100,000$ & 33,905 & 23,660 & 23,660 & 36,523 & 169,141 & 641,595 & 15,657 & 21,587 & 3,222 \\
$\$ 200,000$ & 56,781 & 39,622 & 39,622 & 71,465 & 294,192 & $1,161,141$ & 44,084 & 52,980 & 9,364 \\
$\$ 500,000$ & 138,996 & 96,993 & 96,993 & 166,378 & $1,078,899$ & $3,071,921$ & 125,907 & 153,531 & 42,046 \\
\hline
\end{tabular}


Table 5

Consumption, Assets, and Taxes of Age 50 Households

Assuming a No Benefit Cut

\begin{tabular}{|c|c|c|c|c|c|c|}
\hline \multicolumn{7}{|c|}{ Single, Age 50 Households Experiencing No Benefit Cut } \\
\hline \multirow{2}{*}{$\begin{array}{c}\text { Total } \\
\text { Household } \\
\text { Income }\end{array}$} & \multicolumn{2}{|c|}{ Consumption (\$) } & \multicolumn{2}{|c|}{ Regular Assets (\$) } & \multicolumn{2}{|c|}{ Taxes (\$) } \\
\hline & Age 50 & Age 65 & Age 50 & Age 65 & Age 50 & Age 65 \\
\hline$\$ 10,000$ & \multicolumn{2}{|l|}{3,862} & 953 & 0 & 782 & 0 \\
\hline$\$ 15,000$ & 4,821 & 8,895 & 1,351 & 0 & 2,058 & 0 \\
\hline$\$ 25,000$ & 5,492 & 13,046 & 225 & 997 & 3,864 & 0 \\
\hline$\$ 35,000$ & 6,604 & 16,641 & 0 & 9,538 & 5,803 & 0 \\
\hline$\$ 50,000$ & 8,668 & 21.419 & 0 & 33,851 & 9,055 & 0 \\
\hline$\$ 100,000$ & 13,550 & 29,646 & 0 & 183,869 & 21,897 & 2,524 \\
\hline$\$ 250,000$ & 46,697 & 46,697 & 67,559 & 831,893 & 59,426 & 13,584 \\
\hline \multicolumn{7}{|c|}{ Married, Age 50 Households with No Benefit Cut } \\
\hline \multirow{2}{*}{$\begin{array}{c}\text { Total } \\
\text { Household } \\
\text { Income }\end{array}$} & \multicolumn{2}{|c|}{ Consumption (\$) } & \multicolumn{2}{|c|}{ Regular Assets (\$) } & \multicolumn{2}{|c|}{ Taxes (\$) } \\
\hline & Age 50 & Age 65 & Age 50 & Age 65 & Age 50 & Age 65 \\
\hline$\$ 20,000$ & 6,921 & 14,589 & 2,305 & 868 & 2,193 & 0 \\
\hline$\$ 30,000$ & 8,031 & 17,340 & 1,886 & 1,086 & 4,061 & 0 \\
\hline$\$ 50,000$ & 11,190 & 23,399 & 2,138 & 10,895 & 7,972 & 0 \\
\hline$\$ 70,000$ & 14,039 & 30,150 & 2,394 & 32,864 & 12,206 & 0 \\
\hline$\$ 100,000$ & 18,572 & 39,000 & 3,163 & 82,526 & 18,728 & 776 \\
\hline$\$ 200,000$ & 27,678 & 55,255 & 4,942 & 347,845 & 45,483 & 6,590 \\
\hline$\$ 500,000$ & 106,892 & 106,892 & 632,672 & $2,056,423$ & 126,331 & 35,221 \\
\hline
\end{tabular}


Table 6

Consumption, Assets, and Taxes of Age 50 Households

Assuming a 30 Percent Benefit Cut

\begin{tabular}{|c|c|c|c|c|c|c|}
\hline \multicolumn{7}{|c|}{ Single, Age 50 Households Assuming a 30 Percent Benefit Cut } \\
\hline \multirow{2}{*}{$\begin{array}{c}\text { Total } \\
\text { Household } \\
\text { Income }\end{array}$} & \multicolumn{2}{|c|}{ Consumption (\$) } & \multicolumn{2}{|c|}{ Regular Assets (\$) } & \multicolumn{2}{|c|}{ Taxes (\$) } \\
\hline & Age 50 & Age 65 & Age 50 & Age 65 & Age 50 & Age 65 \\
\hline$\$ 10,000$ & \multicolumn{2}{|l|}{3,862} & 953 & 3,743 & 782 & 0 \\
\hline$\$ 15,000$ & 4,821 & 6,797 & 1,353 & 16,823 & 2,058 & 0 \\
\hline$\$ 25,000$ & 5,492 & 10,320 & 225 & 33,883 & 3,864 & 0 \\
\hline$\$ 35,000$ & 6,604 & 13,383 & 0 & 54,780 & 5,803 & 20 \\
\hline$\$ 50,000$ & 8,668 & 17,431 & 0 & 88,995 & 9,055 & 0 \\
\hline$\$ 100,000$ & 13,550 & 24,697 & 0 & 250,957 & 21,897 & 2,670 \\
\hline$\$ 250,000$ & 42,291 & 42,291 & 71,965 & 899,936 & 59,426 & 12,954 \\
\hline \multicolumn{7}{|c|}{ Married, Age 50 Households Assuming a 30 Percent Benefit Cut } \\
\hline \multirow{2}{*}{$\begin{array}{c}\text { Total } \\
\text { Household } \\
\text { Income }\end{array}$} & \multicolumn{2}{|c|}{ Consumption (\$) } & \multicolumn{2}{|c|}{ Regular Assets (\$) } & \multicolumn{2}{|c|}{ Taxes } \\
\hline & Age 50 & Age 65 & Age 50 & Age 65 & Age 50 & Age 65 \\
\hline$\$ 20,000$ & 6,954 & 10,347 & 2,303 & 8,669 & 2,193 & 0 \\
\hline$\$ 30,000$ & 8,049 & 13,303 & 1,855 & 29,106 & 4,061 & 0 \\
\hline$\$ 50,000$ & 11,358 & 19,149 & 2,142 & 69,402 & 7,810 & 0 \\
\hline$\$ 70,000$ & 14,027 & 24,978 & 2,394 & 108,987 & 12,206 & 0 \\
\hline$\$ 100,000$ & 18,539 & 32,440 & 3,165 & 176,048 & 18,728 & 676 \\
\hline$\$ 200,000$ & 27,650 & 47,032 & 4,943 & 462,519 & 45,483 & 6,157 \\
\hline$\$ 500,000$ & 98,172 & 98,172 & 641,562 & $2,195,922$ & 126,331 & 34,008 \\
\hline
\end{tabular}


Table 7

Consumption, Assets, and Taxes of Age 50 Households

Assuming a 100 Percent Benefit Cut

\begin{tabular}{|c|c|c|c|c|c|c|}
\hline \multicolumn{7}{|c|}{ Single } \\
\hline \multirow{2}{*}{$\begin{array}{c}\text { Total } \\
\text { Household } \\
\text { Income }\end{array}$} & \multicolumn{2}{|c|}{ Consumption (\$) } & \multicolumn{2}{|c|}{ Regular Assets (\$) } & \multicolumn{2}{|c|}{ Taxes $(\$)$} \\
\hline & Age 50 & Age 65 & Age 50 & Age 65 & Age 50 & Age 65 \\
\hline$\$ 10,000$ & 2,215 & 2,215 & 2,606 & 58,002 & 782 & 0 \\
\hline$\$ 15,000$ & 2,863 & 2,863 & 3,319 & 77,824 & 2,058 & 81 \\
\hline$\$ 25,000$ & 4,424 & 4,424 & 1,297 & 120,773 & 3,864 & 0 \\
\hline$\$ 35,000$ & 5,801 & 5,801 & 807 & 164,076 & 5,803 & 316 \\
\hline$\$ 50,000$ & 7,880 & 7,880 & 792 & 223,203 & 9,055 & 465 \\
\hline$\$ 100,000$ & 13,242 & 13,242 & 310 & 408,400 & 21,897 & 2,369 \\
\hline$\$ 250,000$ & 31,823 & 31,823 & 82,433 & $1,061,835$ & 59,426 & 11,530 \\
\hline \multicolumn{7}{|c|}{ Married } \\
\hline \multirow{2}{*}{$\begin{array}{c}\text { Total } \\
\text { Household } \\
\text { Income }\end{array}$} & \multicolumn{2}{|c|}{ Consumption (\$) } & \multicolumn{2}{|c|}{ Regular Assets (\$) } & \multicolumn{2}{|c|}{ Taxes (\$) } \\
\hline & Age 50 & Age 65 & Age 50 & Age 65 & Age 50 & Age 65 \\
\hline$\$ 20,000$ & 4,169 & 4,169 & 5,162 & 110,313 & 2,193 & 0 \\
\hline$\$ 30,000$ & 5,635 & 5,635 & 4,404 & 152,025 & 4,061 & 0 \\
\hline$\$ 50,000$ & 8,501 & 8,501 & 5,157 & 238,171 & 7,810 & 358 \\
\hline$\$ 70,000$ & 11,441 & 11,441 & 5,182 & 318,888 & 12,206 & 195 \\
\hline$\$ 100,000$ & 15,319 & 15,319 & 7,949 & 446,987 & 17,459 & 1,683 \\
\hline$\$ 200,000$ & 24,987 & 24,987 & 8,084 & 787,382 & 45,483 & 4,913 \\
\hline$\$ 500,000$ & 77,477 & 77,477 & 662,729 & $2,526,369$ & 126,331 & 31,624 \\
\hline
\end{tabular}


Table 8

Consumption, Assets, and Taxes of Age 65 Households

Experiencing No Benefit Cut

\begin{tabular}{|c|c|c|c|}
\hline \multicolumn{4}{|c|}{ Single } \\
\hline \multirow{2}{*}{$\begin{array}{c}\text { Total } \\
\text { Household } \\
\text { Income }\end{array}$} & Consumption (\$) & Regular Assets (\$) & Taxes (\$) \\
\hline & Age 65 & Age 65 & Age 65 \\
\hline$\$ 10,000$ & 8,612 & 0 & 0 \\
\hline$\$ 15,000$ & 10,703 & 2 & 0 \\
\hline$\$ 25,000$ & 15,103 & 22,246 & 0 \\
\hline$\$ 35,000$ & 18,098 & 39,606 & 0 \\
\hline$\$ 50,000$ & 21,312 & 73,808 & 0 \\
\hline$\$ 100,000$ & 29,279 & 254,725 & 1,939 \\
\hline$\$ 250,000$ & 49,691 & $1,017,992$ & 15,883 \\
\hline \multicolumn{4}{|c|}{ Married } \\
\hline \multirow{2}{*}{$\begin{array}{c}\text { Total } \\
\text { Household } \\
\text { Income }\end{array}$} & Consumption (\$) & Regular Assets (\$) & Taxes (\$) \\
\hline & Age 65 & Age 65 & Age 65 \\
\hline$\$ 20,000$ & 15,569 & 796 & 0 \\
\hline$\$ 30,000$ & 19,534 & 5,481 & 0 \\
\hline$\$ 50,000$ & 27,825 & 45,829 & 0 \\
\hline$\$ 70,000$ & 34,384 & 94,158 & 0 \\
\hline$\$ 100,000$ & 40,456 & 158,919 & 224 \\
\hline$\$ 200,000$ & 55,247 & 472,290 & 6,298 \\
\hline$\$ 500,000$ & 108,454 & $2,314,952$ & 38,793 \\
\hline
\end{tabular}


Table 9

Consumption, Assets, and Taxes of Age 65 Households

Assuming a 30 Percent Benefit Cut

\begin{tabular}{|c|c|c|c|}
\hline \multicolumn{4}{|c|}{ Single } \\
\hline \multirow{2}{*}{$\begin{array}{c}\text { Total } \\
\text { Household } \\
\text { Income }\end{array}$} & Consumption (\$) & Regular Assets (\$) & Taxes (\$) \\
\hline & Age 65 & Age 65 & Age 65 \\
\hline$\$ 10,000$ & 5,893 & 0 & 0 \\
\hline$\$ 15,000$ & 7,289 & 2 & 0 \\
\hline$\$ 25,000$ & 10,541 & 22,246 & 0 \\
\hline$\$ 35,000$ & 12,742 & 39,606 & 0 \\
\hline$\$ 50,000$ & 15,261 & 73,808 & 0 \\
\hline$\$ 100,000$ & 22,990 & 254,690 & 1,148 \\
\hline$\$ 250,000$ & 43,923 & $1,018,157$ & 14,371 \\
\hline \multicolumn{4}{|c|}{ Married } \\
\hline \multirow{2}{*}{$\begin{array}{c}\text { Total } \\
\text { Household } \\
\text { Income }\end{array}$} & Consumption (\$) & Regular Assets (\$) & Taxes \\
\hline & Age 65 & Age 65 & Age 65 \\
\hline$\$ 20,000$ & 10,555 & 592 & 0 \\
\hline$\$ 30,000$ & 13,238 & 5,226 & 0 \\
\hline$\$ 50,000$ & 19,407 & 45,555 & 0 \\
\hline$\$ 70,000$ & 24,498 & 93,762 & 0 \\
\hline$\$ 100,000$ & 29,541 & 158,317 & 0 \\
\hline$\$ 200,000$ & 42,989 & 472,630 & 4,483 \\
\hline$\$ 500,000$ & 97,087 & $2,315,544$ & 35,338 \\
\hline
\end{tabular}


Table 10

Consumption, Assets, and Taxes of Age 65 Households

Assuming a 100 Percent Benefit Cut

\begin{tabular}{|c|c|c|c|}
\hline \multicolumn{4}{|c|}{ Single } \\
\hline \multirow{2}{*}{$\begin{array}{l}\text { Total } \\
\text { Household } \\
\text { Income }\end{array}$} & Consumption (\$) & Regular Assets (\$) & Taxes $(\$)$ \\
\hline & Age 65 & Age 65 & Age 65 \\
\hline$\$ 10,000$ & 0 & 0 & 0 \\
\hline$\$ 15,000$ & 0 & 0 & 0 \\
\hline$\$ 25,000$ & 0 & 0 & 0 \\
\hline$\$ 35,000$ & 245 & 39,606 & 0 \\
\hline$\$ 50,000$ & 1,141 & 73,808 & 0 \\
\hline$\$ 100,000$ & 6,953 & 254,557 & 716 \\
\hline$\$ 250,000$ & 30,147 & $1,018,859$ & 10,843 \\
\hline \multicolumn{4}{|c|}{ Married } \\
\hline \multirow{2}{*}{$\begin{array}{c}\text { Total } \\
\text { Household } \\
\text { Income }\end{array}$} & Consumption (\$) & Regular Assets (\$) & Taxes (\$) \\
\hline & Age 65 & Age 65 & Age 65 \\
\hline$\$ 20,000$ & 0 & 0 & 0 \\
\hline$\$ 30,000$ & 0 & 0 & 0 \\
\hline$\$ 50,000$ & 0 & 0 & 0 \\
\hline$\$ 70,000$ & 1,123 & 92,992 & 0 \\
\hline$\$ 100,000$ & 2,744 & 157,653 & 0 \\
\hline$\$ 200,000$ & 12,204 & 473,115 & 1,579 \\
\hline$\$ 500,000$ & 69,854 & $2,317,292$ & 27,619 \\
\hline
\end{tabular}


Table 11

Percentage Reduction in Living Standard of Age 35 Households Assuming 30 and 100 Percent Benefit Cuts

\begin{tabular}{|c|c|c|c|c|c|c|}
\hline \multicolumn{7}{|c|}{ Single } \\
\hline \multirow{2}{*}{$\begin{array}{c}\text { Total } \\
\text { Household } \\
\text { Income }\end{array}$} & \multicolumn{3}{|c|}{$30 \%$ Benefit Cut } & \multicolumn{3}{|c|}{$100 \%$ Benefit Cut } \\
\hline & Age 35 & Age 50 & Age 65 & Age 35 & Age 50 & Age 65 \\
\hline$\$ 10,000$ & $0.1 \%$ & $0.1 \%$ & $26.4 \%$ & $26.6 \%$ & $26.6 \%$ & $56.6 \%$ \\
\hline$\$ 15,000$ & $0.1 \%$ & $0.1 \%$ & $21.1 \%$ & $24.2 \%$ & $24.2 \%$ & $49.8 \%$ \\
\hline$\$ 25,000$ & $0.1 \%$ & $0.1 \%$ & $18.4 \%$ & $17.3 \%$ & $17.3 \%$ & $48.4 \%$ \\
\hline$\$ 35,000$ & $0.1 \%$ & $0 \%$ & $17.7 \%$ & $14.7 \%$ & $18.9 \%$ & $51.4 \%$ \\
\hline$\$ 50,000$ & $0.1 \%$ & $0 \%$ & $17.6 \%$ & $15.9 \%$ & $20.9 \%$ & $49.8 \%$ \\
\hline$\$ 100,000$ & $0 \%$ & $0 \%$ & $15.4 \%$ & $16.3 \%$ & $21.0 \%$ & $41.6 \%$ \\
\hline$\$ 250,000$ & $5.2 \%$ & $5.2 \%$ & $5.2 \%$ & $17.6 \%$ & $17.6 \%$ & $17.6 \%$ \\
\hline \multicolumn{7}{|c|}{ Married } \\
\hline \multirow{2}{*}{$\begin{array}{l}\text { Total } \\
\text { Household } \\
\text { Income }\end{array}$} & \multicolumn{3}{|c|}{$30 \%$ Benefit Cut } & \multicolumn{3}{|c|}{$100 \%$ Benefit Cut } \\
\hline & Age 35 & Age 50 & Age 65 & Age 35 & Age 50 & Age 65 \\
\hline$\$ 20,000$ & $0.4 \%$ & $0.4 \%$ & $25.2 \%$ & $29.2 \%$ & $29.2 \%$ & $56.7 \%$ \\
\hline$\$ 30,000$ & $0.5 \%$ & $0.5 \%$ & $17.8 \%$ & $23.5 \%$ & $23.5 \%$ & $50.7 \%$ \\
\hline$\$ 50,000$ & $0.4 \%$ & $0.4 \%$ & $16.2 \%$ & $21.2 \%$ & $21.2 \%$ & $47.4 \%$ \\
\hline$\$ 70,000$ & $0.4 \%$ & $0.4 \%$ & $15.9 \%$ & $22.0 \%$ & $22.0 \%$ & $46.1 \%$ \\
\hline$\$ 100,000$ & $0.3 \%$ & $0.3 \%$ & $15.7 \%$ & $22.7 \%$ & $22.7 \%$ & $45.3 \%$ \\
\hline$\$ 200,000$ & $0.1 \%$ & $0.1 \%$ & $15.2 \%$ & $23.8 \%$ & $23.8 \%$ & $39.0 \%$ \\
\hline$\$ 500,000$ & $5.3 \%$ & $5.3 \%$ & $5.3 \%$ & $17.9 \%$ & $17.9 \%$ & $17.9 \%$ \\
\hline
\end{tabular}


Table 12

Percentage Reductions in Living Standard of Age 50 Households Assuming 30 and 100 Percent Benefit Cuts

\begin{tabular}{|c|c|c|c|c|}
\hline \multicolumn{5}{|c|}{$\begin{array}{c}\text { Single, Age } 50 \text { Households' Percentage } \\
\text { Decline in Living Standard }\end{array}$} \\
\hline \multirow{2}{*}{$\begin{array}{l}\text { Total Household } \\
\text { Income }\end{array}$} & \multicolumn{2}{|c|}{$30 \%$ Benefit Cut } & \multicolumn{2}{|c|}{ 100\% Benefit Cut } \\
\hline & Age 50 & Age 65 & Age 50 & Age 65 \\
\hline$\$ 10,000$ & $0 \%$ & $29.5 \%$ & $42.6 \%$ & $73.0 \%$ \\
\hline$\$ 15,000$ & $0 \%$ & $23.6 \%$ & $40.6 \%$ & $67.8 \%$ \\
\hline$\$ 25,000$ & $0 \%$ & $20.9 \%$ & $19.4 \%$ & $66.1 \%$ \\
\hline$\$ 35,000$ & $0 \%$ & $19.6 \%$ & $12.2 \%$ & $65.1 \%$ \\
\hline$\$ 50,000$ & $0 \%$ & $18.6 \%$ & $9.1 \%$ & $63.2 \%$ \\
\hline$\$ 100,000$ & $0 \%$ & $16.7 \%$ & $2.3 \%$ & $55.3 \%$ \\
\hline$\$ 250,000$ & $9.4 \%$ & $9.4 \%$ & $31.9 \%$ & $31.9 \%$ \\
\hline \multicolumn{5}{|c|}{$\begin{array}{c}\text { Married, Age } 50 \text { Households' Percentage Decline in Living } \\
\text { Standard }\end{array}$} \\
\hline \multirow{2}{*}{$\begin{array}{l}\text { Total Household } \\
\text { Income }\end{array}$} & \multicolumn{2}{|c|}{$30 \%$ Benefit Cut } & \multicolumn{2}{|c|}{ 100\% Benefit Cut } \\
\hline & Age 50 & Age 65 & Age 50 & Age 65 \\
\hline$\$ 20,000$ & $-0.5 \%$ & $29.1 \%$ & $39.8 \%$ & $71.4 \%$ \\
\hline$\$ 30,000$ & $-0.2 \%$ & $23.3 \%$ & $29.8 \%$ & $67.5 \%$ \\
\hline$\$ 50,000$ & $-1.5 \%$ & $18.2 \%$ & $24.0 \%$ & $63.7 \%$ \\
\hline$\$ 70,000$ & $0.1 \%$ & $17.2 \%$ & $18.5 \%$ & $62.1 \%$ \\
\hline$\$ 100,000$ & $0.2 \%$ & $16.8 \%$ & $17.5 \%$ & $60.7 \%$ \\
\hline$\$ 200,000$ & $0.1 \%$ & $14.9 \%$ & $9.7 \%$ & $54.8 \%$ \\
\hline$\$ 500,000$ & $8.2 \%$ & $8.2 \%$ & $27.5 \%$ & $27.5 \%$ \\
\hline
\end{tabular}


Table 13

Percentage Reductions in Living Standard of Age 50 Households Assuming 30 and 100 Percent Benefit Cuts

\begin{tabular}{|c|c|c|}
\hline \multicolumn{3}{|c|}{$\begin{array}{c}\text { Single, Age } 65 \text { Households' Percentage } \\
\text { Decline in Living Standard }\end{array}$} \\
\hline \multirow{2}{*}{$\begin{array}{l}\text { Total } \\
\text { Household } \\
\text { Income }\end{array}$} & $30 \%$ Benefit Cut & $100 \%$ Benefit Cut \\
\hline & Age 65 & Age 65 \\
\hline$\$ 10,000$ & $31.6 \%$ & $100 \%$ \\
\hline$\$ 15,000$ & $31.9 \%$ & $100 \%$ \\
\hline$\$ 25,000$ & $30.2 \%$ & $100 \%$ \\
\hline$\$ 35,000$ & $29.6 \%$ & $98.6 \%$ \\
\hline$\$ 50,000$ & $28.4 \%$ & $94.6 \%$ \\
\hline$\$ 100,000$ & $21.5 \%$ & $76.3 \%$ \\
\hline$\$ 250,000$ & $11.6 \%$ & $39.3 \%$ \\
\hline \multicolumn{3}{|c|}{ Married, Age 65 Households' Percentage } \\
\hline \multicolumn{3}{|c|}{ Decline in Living Standard } \\
\hline \multirow{2}{*}{$\begin{array}{l}\text { Total } \\
\text { Household } \\
\text { Income }\end{array}$} & $30 \%$ Benefit Cut & $100 \%$ Benefit Cut \\
\hline & Age 65 & Age 65 \\
\hline$\$ 20,000$ & $32.2 \%$ & $100 \%$ \\
\hline$\$ 30,000$ & $32.2 \%$ & $100 \%$ \\
\hline$\$ 50,000$ & $30.3 \%$ & $100 \%$ \\
\hline$\$ 70,000$ & $28.8 \%$ & $96.7 \%$ \\
\hline$\$ 100,000$ & $26.8 \%$ & $93.2 \%$ \\
\hline$\$ 200,000$ & $22.2 \%$ & $77.9 \%$ \\
\hline$\$ 500,000$ & $10.5 \%$ & $35.6 \%$ \\
\hline
\end{tabular}




\begin{tabular}{|c|c|c|c|c|c|}
\hline \multicolumn{6}{|c|}{$\begin{array}{c}\text { Table } 14 \\
\text { Summary Statistics }\end{array}$} \\
\hline \multicolumn{6}{|c|}{ Percentage reduction in Immediate Living Standard, All Age Groups } \\
\hline \multicolumn{6}{|c|}{$30 \%$ Cut } \\
\hline Age & Mean & $\begin{array}{c}\text { Standard } \\
\text { Deviation } \\
\end{array}$ & Median & Min & Max \\
\hline $25-44$ & $4.4 \%$ & $5.6 \%$ & $2.1 \%$ & $-2.3 \%$ & $29.8 \%$ \\
\hline $45-64$ & $5.7 \%$ & $5.9 \%$ & $3.8 \%$ & $-2.4 \%$ & $21.9 \%$ \\
\hline $65+$ & $17.5 \%$ & $13.7 \%$ & $13.8 \%$ & $-1.2 \%$ & $55.1 \%$ \\
\hline Total & $7.2 \%$ & $9.0 \%$ & $4.2 \%$ & $-2.4 \%$ & $55.1 \%$ \\
\hline \multicolumn{6}{|c|}{$100 \%$ Cut } \\
\hline Age & mean & $\begin{array}{c}\text { Standard } \\
\text { Deviation }\end{array}$ & median & $\min$ & $\max$ \\
\hline $25-44$ & $17.4 \%$ & $18.1 \%$ & $13.0 \%$ & $-2.2 \%$ & $96.5 \%$ \\
\hline $45-64$ & $21.7 \%$ & $20.1 \%$ & $17.9 \%$ & $-1.1 \%$ & $100.0 \%$ \\
\hline $65+$ & $51.3 \%$ & $34.8 \%$ & $43.0 \%$ & $0.8 \%$ & $100.0 \%$ \\
\hline Total & $25.1 \%$ & $25.6 \%$ & $19.5 \%$ & $-2.2 \%$ & $100.0 \%$ \\
\hline
\end{tabular}




\begin{tabular}{|c|c|c|c|c|c|}
\hline \multicolumn{5}{|c|}{$\begin{array}{l}\text { Percentage Reduction in Age-65 Living Standard } \\
\text { of Households Age 25-44 and Age 45-64 }\end{array}$} & \\
\hline \multicolumn{6}{|c|}{$30 \%$ Cut } \\
\hline Age & Mean & $\begin{array}{c}\text { Standard } \\
\text { Deviation }\end{array}$ & Median & Min & Max \\
\hline $25-44$ & $10.0 \%$ & $4.9 \%$ & $9.6 \%$ & $-1.2 \%$ & $29.8 \%$ \\
\hline $45-64$ & $7.5 \%$ & $6.2 \%$ & $7.8 \%$ & $-2.4 \%$ & $22.3 \%$ \\
\hline Total & $8.7 \%$ & $5.8 \%$ & $8.8 \%$ & $-2.4 \%$ & $29.8 \%$ \\
\hline \multicolumn{6}{|c|}{$100 \%$ Cut } \\
\hline Age & mean & $\begin{array}{c}\text { Standard } \\
\text { Deviation }\end{array}$ & median & $\min$ & $\max$ \\
\hline $25-44$ & $30.8 \%$ & $13.4 \%$ & $30.7 \%$ & $0.0 \%$ & $96.5 \%$ \\
\hline $45-64$ & $24.7 \%$ & $20.1 \%$ & $24.1 \%$ & $-1.1 \%$ & $100.0 \%$ \\
\hline Total & $27.5 \%$ & $17.6 \%$ & $29.2 \%$ & $-1.1 \%$ & $100.0 \%$ \\
\hline
\end{tabular}




\begin{tabular}{|c|c|c|c|c|c|c|c|c|c|c|c|c|c|}
\hline \multicolumn{14}{|c|}{ Percentage of Households by magnitude of Percentage Reduction } \\
\hline $\begin{array}{c}\text { Marital } \\
\text { Status }\end{array}$ & Age group & $\begin{array}{l}\text { Less or } \\
\text { equal zero }\end{array}$ & $0-10 \%$ & $10-20 \%$ & $20-30 \%$ & $30-40 \%$ & $40-50 \%$ & $50-60 \%$ & $60-70 \%$ & $70-80 \%$ & $80-90 \%$ & $>90 \%$ & TOTAL \\
\hline \multirow{3}{*}{ Single } & $25-44$ & $11 \%$ & $68 \%$ & $16 \%$ & $5 \%$ & $0 \%$ & $0 \%$ & $0 \%$ & $0 \%$ & $0 \%$ & $0 \%$ & $0 \%$ & $100 \%$ \\
\hline & $45-64$ & $20 \%$ & $59 \%$ & $21 \%$ & $0 \%$ & $0 \%$ & $0 \%$ & $0 \%$ & $0 \%$ & $0 \%$ & $0 \%$ & $0 \%$ & $100 \%$ \\
\hline & $65+$ & $3 \%$ & $7 \%$ & $45 \%$ & $13 \%$ & $25 \%$ & $8 \%$ & $0 \%$ & $0 \%$ & $0 \%$ & $0 \%$ & $0 \%$ & $100 \%$ \\
\hline \multirow{3}{*}{ Couples } & $25-44$ & $19 \%$ & $79 \%$ & $3 \%$ & $0 \%$ & $0 \%$ & $0 \%$ & $0 \%$ & $0 \%$ & $0 \%$ & $0 \%$ & $0 \%$ & $100 \%$ \\
\hline & $45-64$ & $6 \%$ & $48 \%$ & $44 \%$ & $3 \%$ & $0 \%$ & $0 \%$ & $0 \%$ & $0 \%$ & $0 \%$ & $0 \%$ & $0 \%$ & $100 \%$ \\
\hline & $65+$ & $0 \%$ & $26 \%$ & $33 \%$ & $7 \%$ & $25 \%$ & $0 \%$ & $8 \%$ & $0 \%$ & $0 \%$ & $0 \%$ & $0 \%$ & $100 \%$ \\
\hline
\end{tabular}




\begin{tabular}{|c|c|c|c|c|c|c|c|c|c|c|c|c|c|}
\hline \multicolumn{14}{|c|}{ Percentage of Households by magnitude of Percentage Reduction } \\
\hline $\begin{array}{c}\text { Marital } \\
\text { Status }\end{array}$ & Age group & $\begin{array}{l}\text { Less or } \\
\text { equal zero }\end{array}$ & $0-10 \%$ & $10-20 \%$ & $20-30 \%$ & $30-40 \%$ & $40-50 \%$ & $50-60 \%$ & $60-70 \%$ & $70-80 \%$ & $80-90 \%$ & $>90 \%$ & TOTAL \\
\hline \multirow{3}{*}{ Single } & $25-44$ & $5 \%$ & $35 \%$ & $11 \%$ & $17 \%$ & $20 \%$ & $2 \%$ & $4 \%$ & $2 \%$ & $0 \%$ & $0 \%$ & $3 \%$ & $100 \%$ \\
\hline & $45-64$ & $15 \%$ & $26 \%$ & $6 \%$ & $20 \%$ & $8 \%$ & $14 \%$ & $10 \%$ & $0 \%$ & $0 \%$ & $0 \%$ & $0 \%$ & $100 \%$ \\
\hline & $65+$ & $0 \%$ & $3 \%$ & $7 \%$ & $0 \%$ & $17 \%$ & $21 \%$ & $6 \%$ & $5 \%$ & $0 \%$ & $8 \%$ & $33 \%$ & $100 \%$ \\
\hline \multirow{3}{*}{ Couples } & $25-44$ & $11 \%$ & $50 \%$ & $16 \%$ & $14 \%$ & $7 \%$ & $3 \%$ & $0 \%$ & $0 \%$ & $0 \%$ & $0 \%$ & $0 \%$ & $100 \%$ \\
\hline & $45-64$ & $3 \%$ & $8 \%$ & $7 \%$ & $21 \%$ & $32 \%$ & $12 \%$ & $14 \%$ & $0 \%$ & $3 \%$ & $0 \%$ & $0 \%$ & $100 \%$ \\
\hline & $65+$ & $0 \%$ & $0 \%$ & $8 \%$ & $9 \%$ & $11 \%$ & $14 \%$ & $9 \%$ & $8 \%$ & $0 \%$ & $0 \%$ & $41 \%$ & $100 \%$ \\
\hline
\end{tabular}




\begin{tabular}{|c|c|c|c|c|c|c|c|c|c|c|c|c|c|}
\hline \multicolumn{14}{|c|}{ Percentage of Households by magnitude of Percentage Reduction } \\
\hline $\begin{array}{c}\text { Marital } \\
\text { Status }\end{array}$ & Age group & $\begin{array}{l}\text { Less or } \\
\text { equal zero }\end{array}$ & $0-10 \%$ & $10-20 \%$ & $20-30 \%$ & $30-40 \%$ & $40-50 \%$ & $50-60 \%$ & $60-70 \%$ & $70-80 \%$ & $80-90 \%$ & $>90 \%$ & TOTAL \\
\hline \multirow{2}{*}{ Single } & $25-44$ & $2 \%$ & $37 \%$ & $56 \%$ & $5 \%$ & $0 \%$ & $0 \%$ & $0 \%$ & $0 \%$ & $0 \%$ & $0 \%$ & $0 \%$ & $100 \%$ \\
\hline & $45-64$ & $6 \%$ & $50 \%$ & $44 \%$ & $0 \%$ & $0 \%$ & $0 \%$ & $0 \%$ & $0 \%$ & $0 \%$ & $0 \%$ & $0 \%$ & $100 \%$ \\
\hline \multirow{2}{*}{ Couples } & $25-44$ & $0 \%$ & $59 \%$ & $41 \%$ & $0 \%$ & $0 \%$ & $0 \%$ & $0 \%$ & $0 \%$ & $0 \%$ & $0 \%$ & $0 \%$ & $100 \%$ \\
\hline & $45-64$ & $5 \%$ & $31 \%$ & $54 \%$ & $10 \%$ & $0 \%$ & $0 \%$ & $0 \%$ & $0 \%$ & $0 \%$ & $0 \%$ & $0 \%$ & $100 \%$ \\
\hline
\end{tabular}




\begin{tabular}{|c|c|c|c|c|c|c|c|c|c|c|c|c|c|}
\hline \multicolumn{14}{|c|}{ Percentage of Households by magnitude of Percentage Reduction } \\
\hline $\begin{array}{c}\text { Marital } \\
\text { Status }\end{array}$ & Age group & $\begin{array}{l}\text { Less or } \\
\text { equal zero }\end{array}$ & $0-10 \%$ & $10-20 \%$ & $20-30 \%$ & $30-40 \%$ & $40-50 \%$ & $50-60 \%$ & $60-70 \%$ & $70-80 \%$ & $80-90 \%$ & $>90 \%$ & TOTAL \\
\hline \multirow{2}{*}{ Single } & $25-44$ & $2 \%$ & $0 \%$ & $7 \%$ & $26 \%$ & $52 \%$ & $4 \%$ & $4 \%$ & $2 \%$ & $0 \%$ & $0 \%$ & $3 \%$ & $100 \%$ \\
\hline & $45-64$ & $6 \%$ & $21 \%$ & $5 \%$ & $29 \%$ & $8 \%$ & $20 \%$ & $10 \%$ & $0 \%$ & $0 \%$ & $0 \%$ & $0 \%$ & $100 \%$ \\
\hline \multirow{2}{*}{ Couples } & $25-44$ & $0 \%$ & $3 \%$ & $9 \%$ & $34 \%$ & $48 \%$ & $6 \%$ & $0 \%$ & $0 \%$ & $0 \%$ & $0 \%$ & $0 \%$ & $100 \%$ \\
\hline & $45-64$ & $3 \%$ & $2 \%$ & $6 \%$ & $19 \%$ & $34 \%$ & $12 \%$ & $21 \%$ & $0 \%$ & $3 \%$ & $0 \%$ & $0 \%$ & $100 \%$ \\
\hline
\end{tabular}




\begin{tabular}{|c|c|c|c|c|}
\hline \multicolumn{5}{|c|}{ Table 18} \\
\hline \multicolumn{5}{|c|}{ Regression Analysis Explaining Percentage Reduction in Living Standard* } \\
\hline & $\begin{array}{l}\text { current reduction } \\
\text { after } 30 \text { percent cut }\end{array}$ & $\begin{array}{l}\text { current reduction } \\
\text { after } 100 \text { percent cut }\end{array}$ & $\begin{array}{c}\text { reduction at } 65 \text { after } \\
30 \text { percent cut }\end{array}$ & $\begin{array}{c}\text { reduction at } 65 \text { after } \\
100 \text { percent cut }\end{array}$ \\
\hline Marital status & $\begin{array}{c}0.10094 \\
(1.051)\end{array}$ & $\begin{array}{l}1.4367 \\
(2.862)\end{array}$ & $\begin{array}{l}0.368 \\
(0.75)\end{array}$ & $\begin{array}{l}2.796 \\
(2.19)\end{array}$ \\
\hline Age of head & $\begin{array}{l}0.2659 * * \\
(0.336)\end{array}$ & $\begin{array}{l}0.7484 \\
(0.091)\end{array}$ & $\begin{array}{l}0.012 \\
(0.03)\end{array}$ & $\begin{array}{l}0.083 \\
(0.10)\end{array}$ \\
\hline Standard of living ratio & $\begin{array}{c}-13.7202 * * \\
(2.305)\end{array}$ & $\begin{array}{c}-38.7425 * * \\
(6.274)\end{array}$ & $\begin{array}{l}-7.671 * * \\
(1.75)\end{array}$ & $\begin{array}{c}-23.913 * * \\
(5.06)\end{array}$ \\
\hline Standard of living ratio squared & $\begin{array}{l}0.7017 \text { ** } \\
(0.184)\end{array}$ & $\begin{array}{l}1.9591 * * \\
(.5025783)\end{array}$ & $\begin{array}{c}0.484 * * \\
(0.18)\end{array}$ & $\begin{array}{c}1.487 * * \\
(0.53)\end{array}$ \\
\hline Liquidity constraint & $\begin{array}{c}-8.3731 * * \\
(1.166)\end{array}$ & $\begin{array}{c}-21.1555 * * \\
(3.174)\end{array}$ & $\begin{array}{c}-0.149 \\
(0.77)\end{array}$ & $\begin{array}{c}-4.077 \text { * } \\
(2.23)\end{array}$ \\
\hline R - SQUARED & $53.4 \%$ & $52.9 \%$ & $11.5 \%$ & $13.5 \%$ \\
\hline
\end{tabular}

*Standard errors in parentheses 
Figure 1

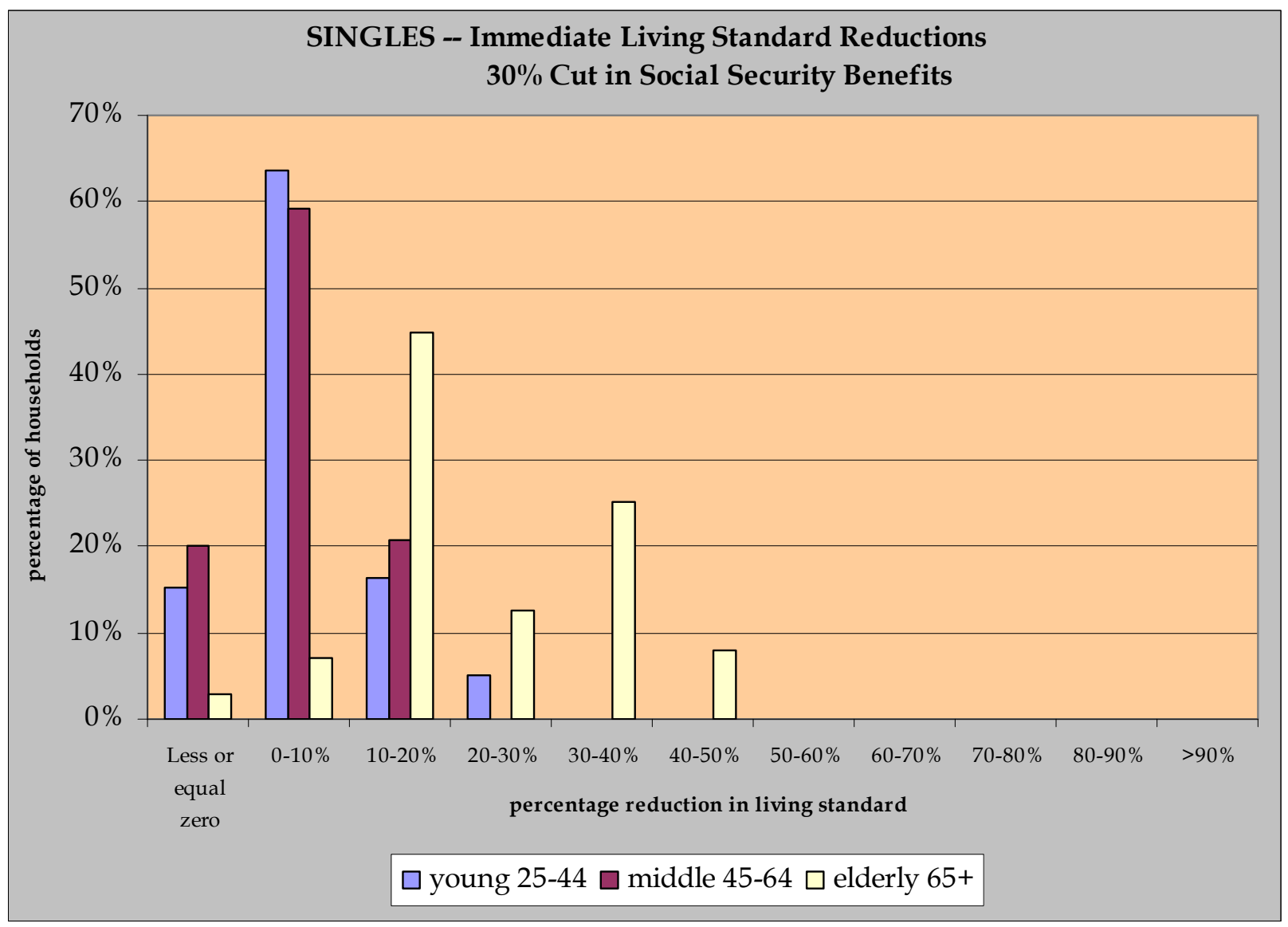


Figure 2

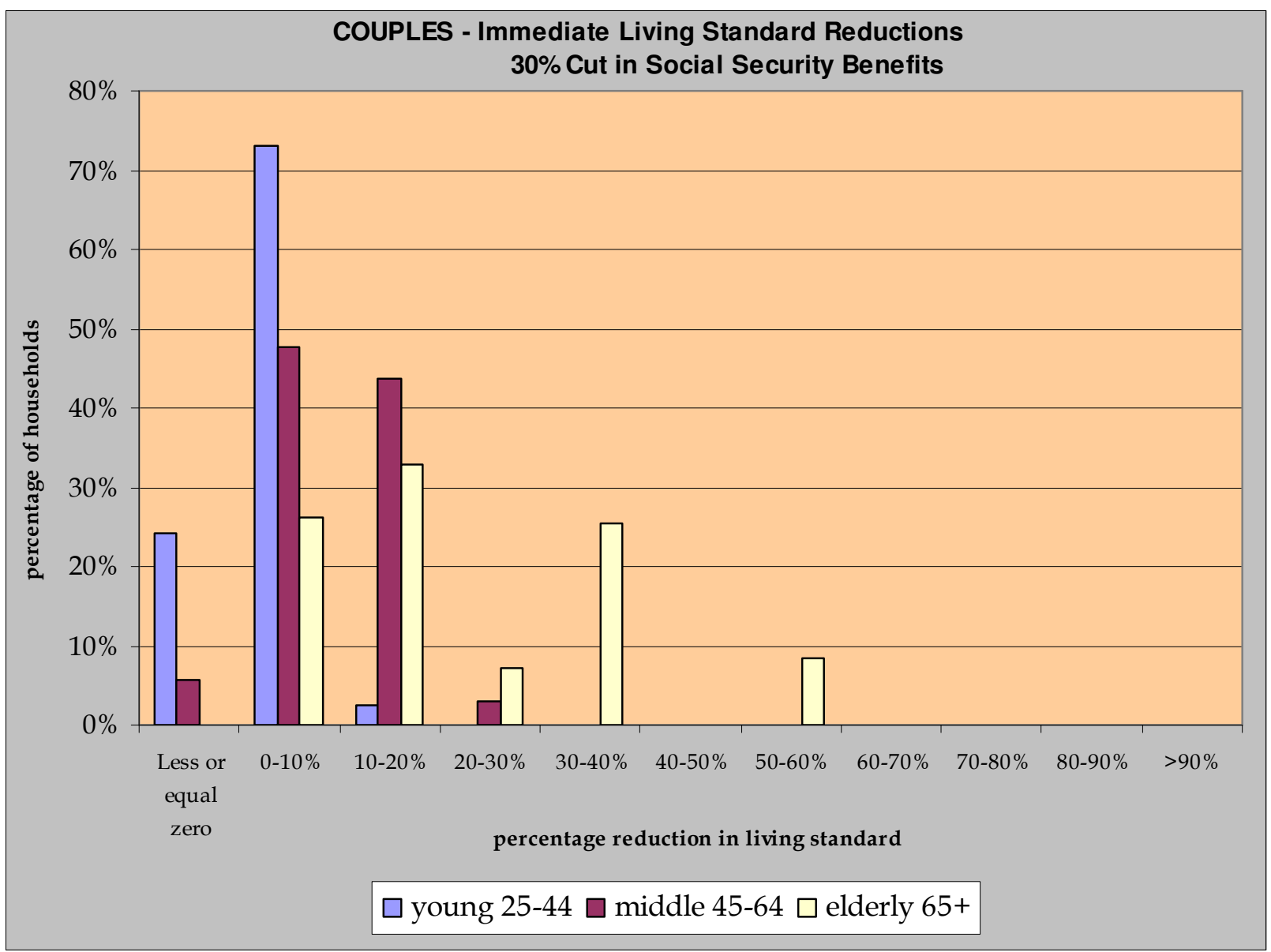


Figure 3

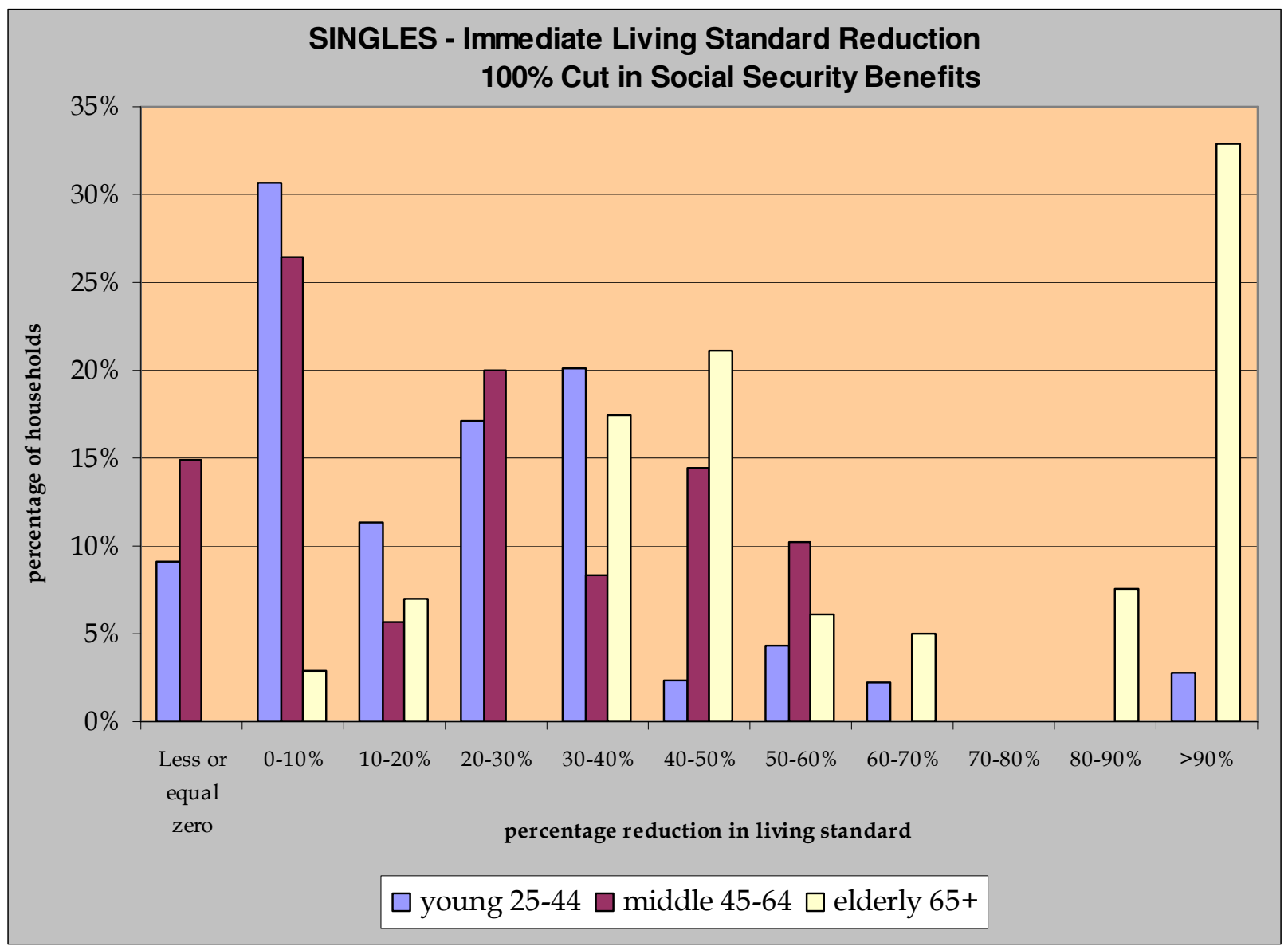


Figure 4

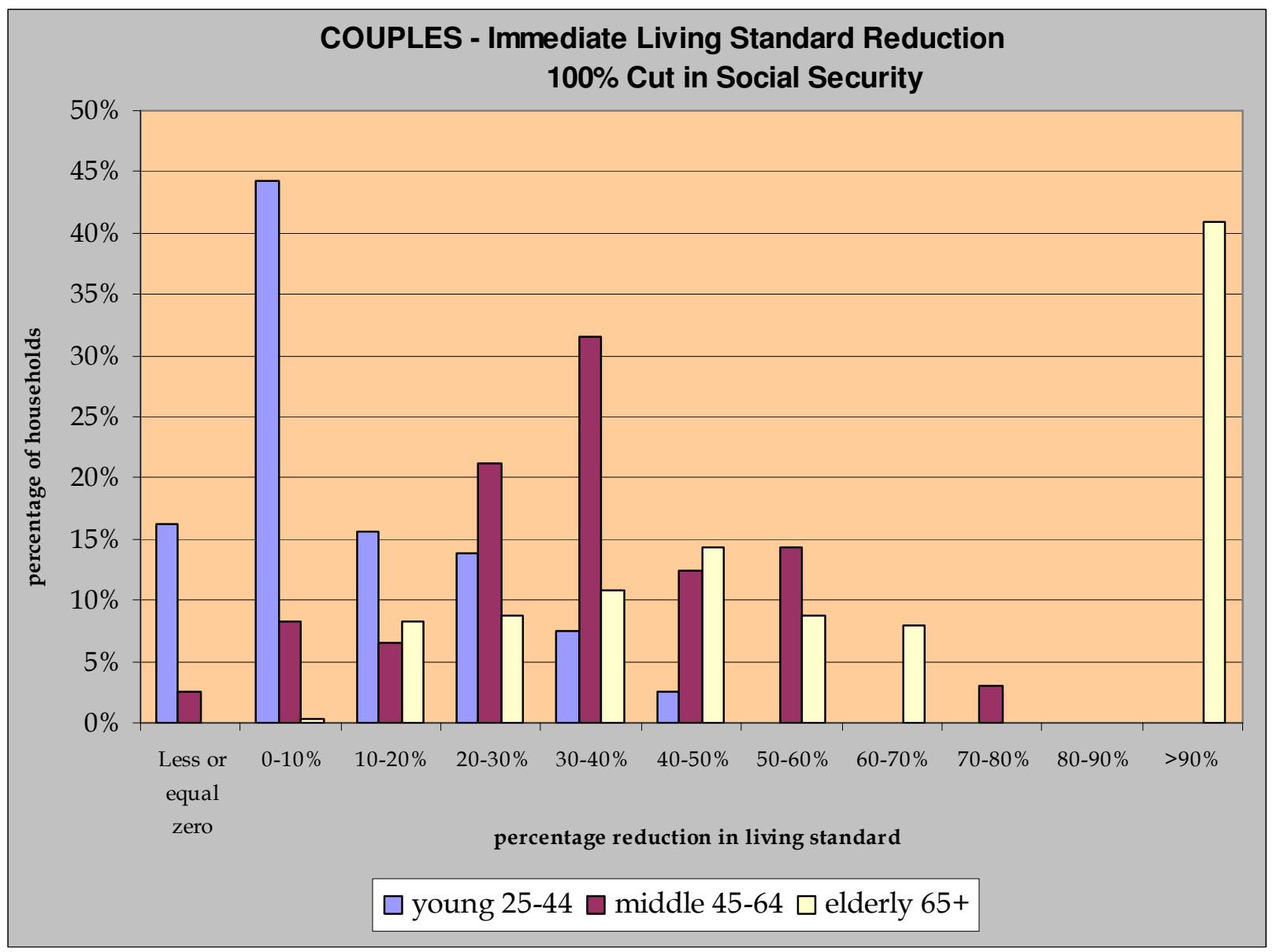


Figure 5

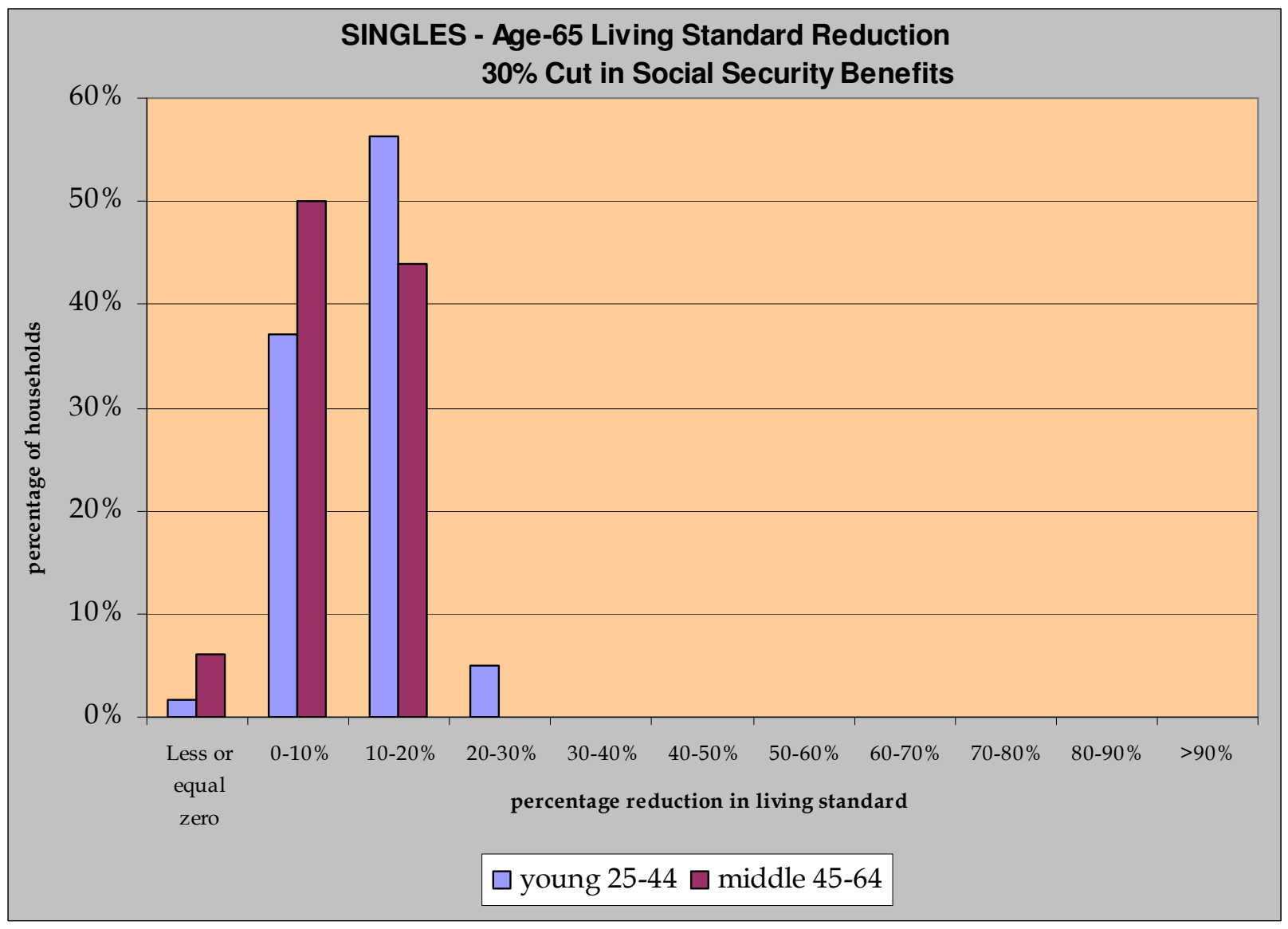


Figure 6

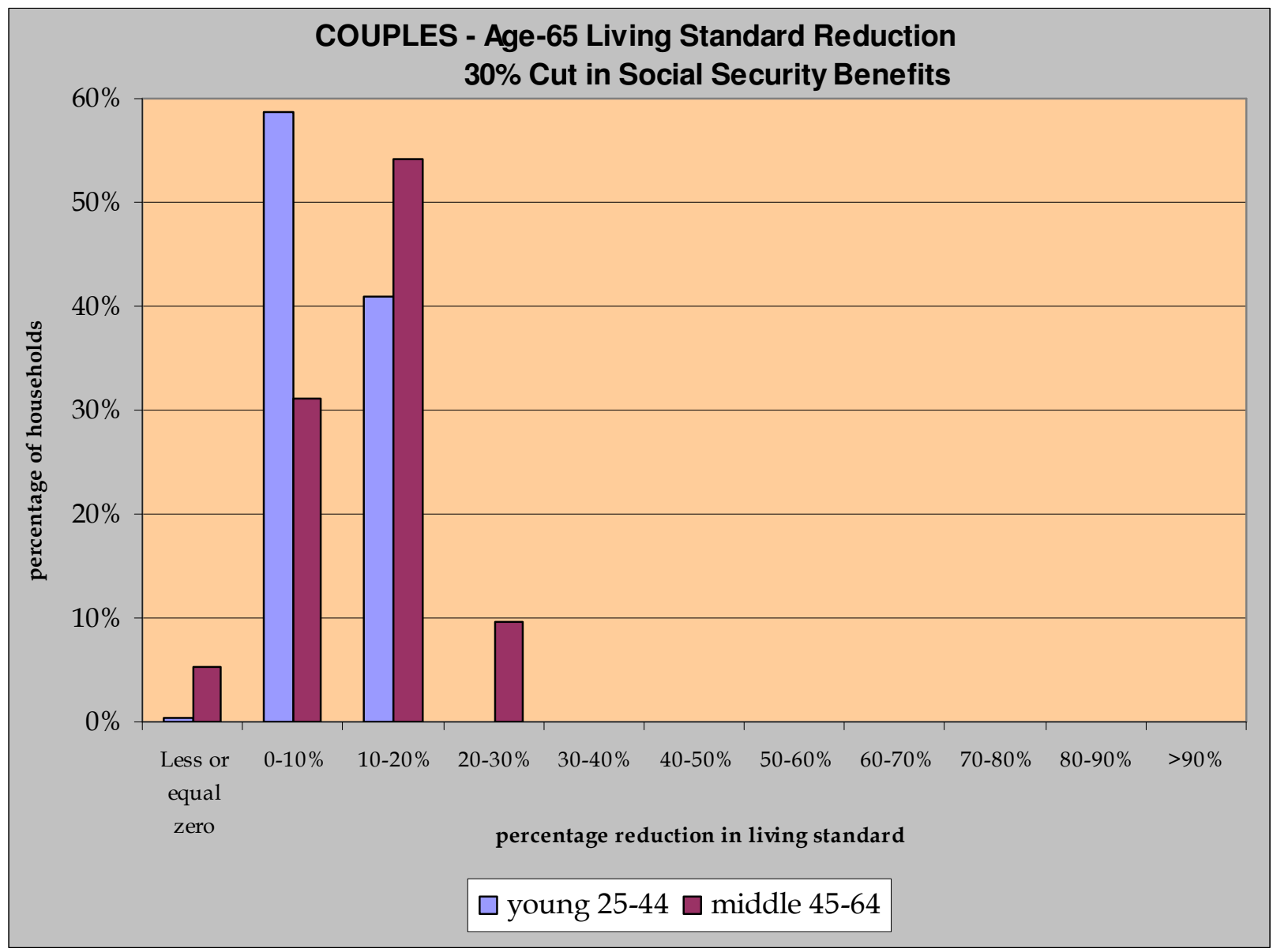


Figure 7

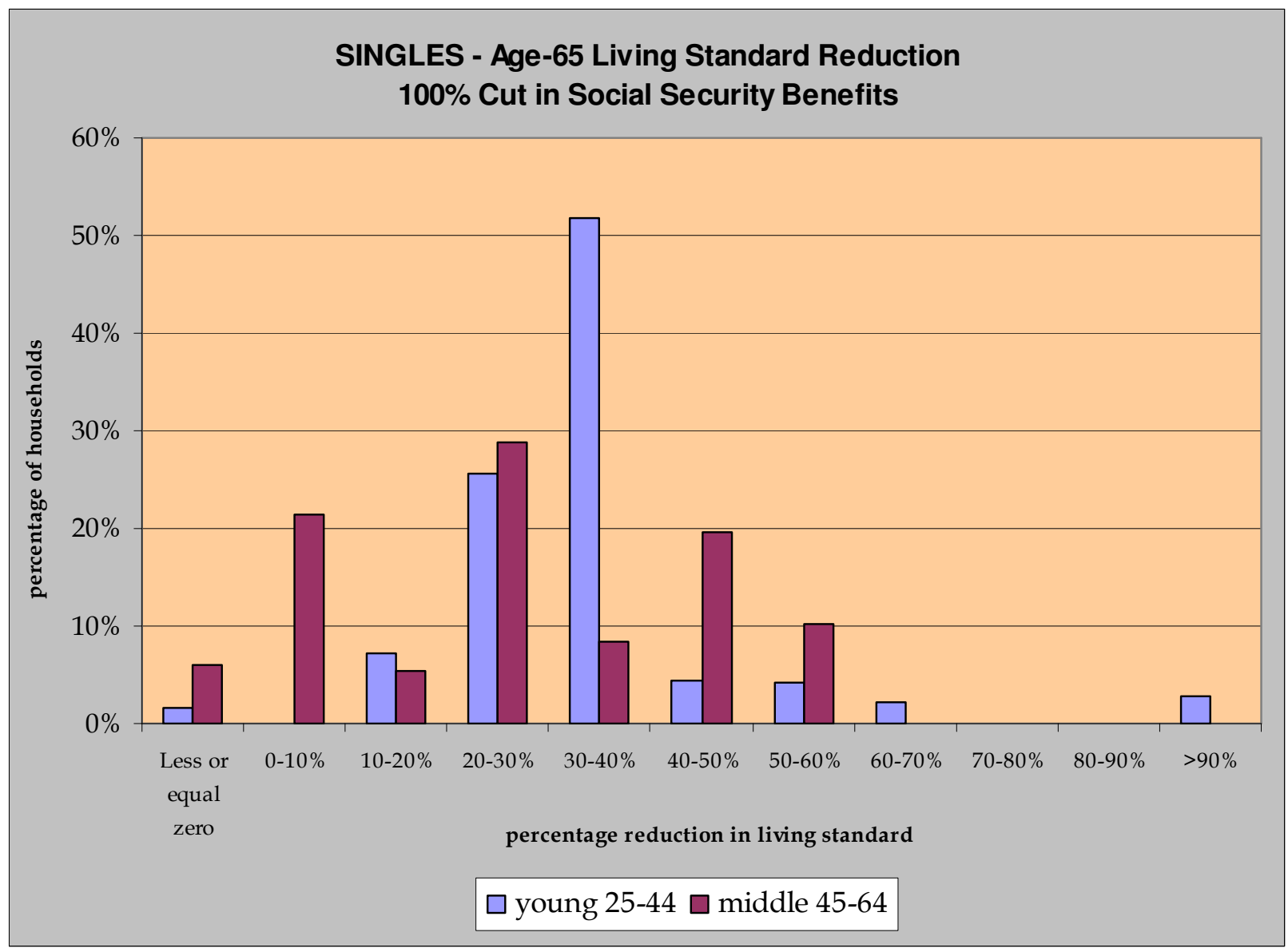




\section{Figure 8}

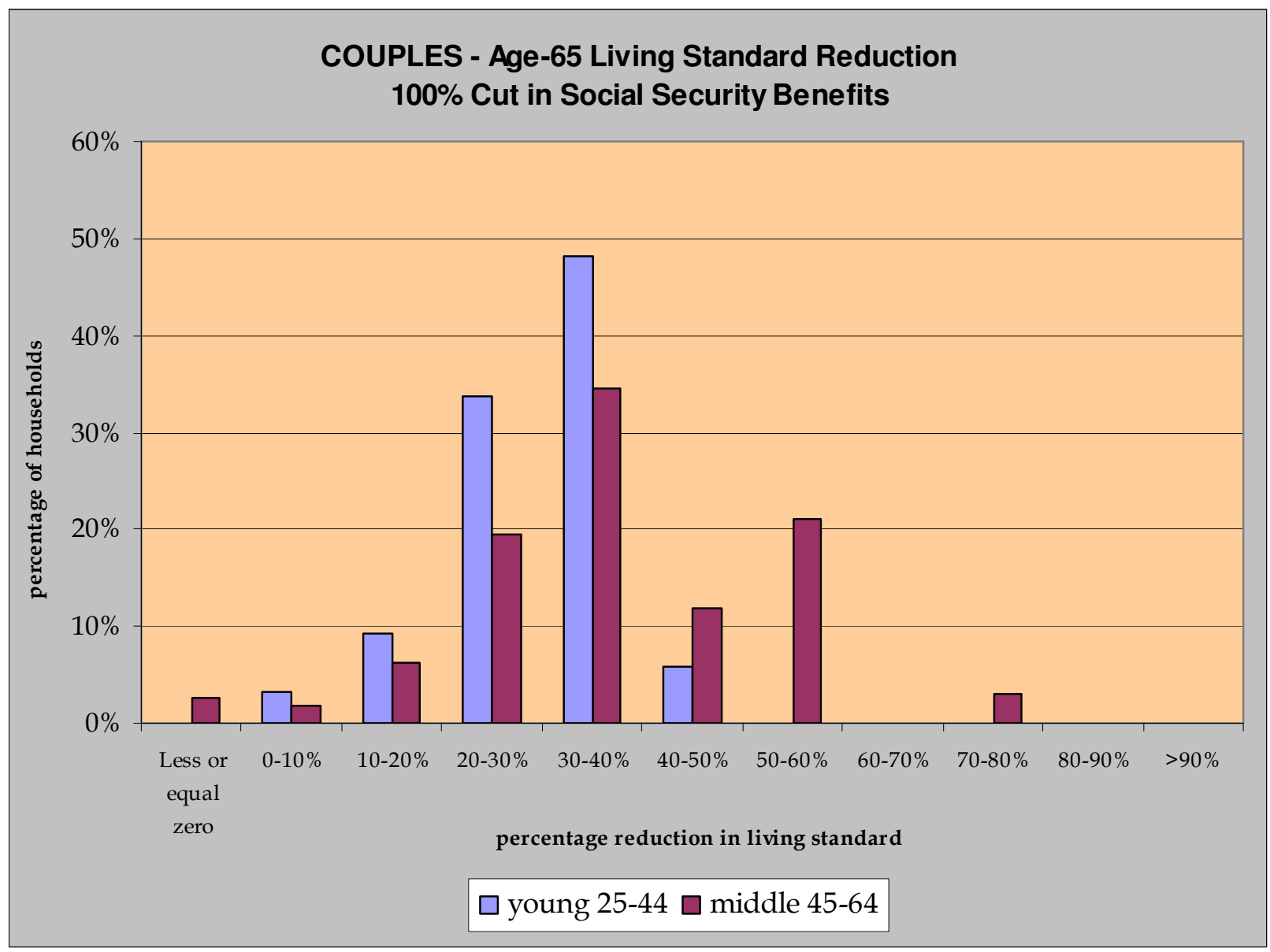

